\title{
The place beyond the trees: renewed excavations of the Middle Stone Age deposits at Olieboomspoort in the Waterberg Mountains of the South African Savanna Biome
}

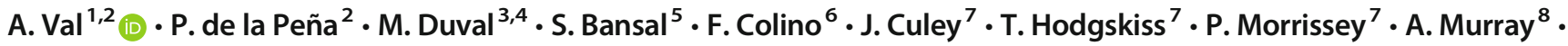 \\ M. Murungi ${ }^{2} \cdot$ F.H. Neumann ${ }^{2} \cdot$ K. Shadrach ${ }^{7}$ K.J. Thomsen ${ }^{8} \cdot$ M. van der Ryst ${ }^{9} \cdot$ D.M. Witelson ${ }^{5} \cdot$ J.X. Zhao ${ }^{10}{ }^{\circ}$ \\ D. Stratford ${ }^{7}$
}

Received: 25 June 2020 / Accepted: 10 February 2021 / Published online: 17 June 2021

(C) The Author(s) 2021

\begin{abstract}
Olieboomspoort is one of the few rock shelters in the vast interior of southern Africa documenting pulses of occupation from the Acheulean until the end of the Later Stone Age. Revil Mason excavated the site in 1954 and attributed the large Middle Stone Age (MSA) lithic assemblage to his middle phase of the so-called Pietersburg Industry. Recent work at the site has focused on the Holocene layers, but little is known about the earlier phases of shelter use. Here, we provide some background to the shelter, give a history of past research and present initial results following renewed fieldwork at the site. The MSA deposits contain abundant lithic artefacts and ochre, and we present an initial description of these cultural remains. Palynological analysis reveals limited potential for palaeoenvironmental reconstructions, but some faunal remains indicate open grasslands. We dated two equid teeth that provided highly consistent combined U-series-ESR estimates, resulting in a mean age of $150 \pm 14 \mathrm{ka}(1 \sigma)$. Even when considering potential sources of uncertainty such as variations in water-intake, these fossils can securely be dated to Marine Isotopic Stage 6. Our reappraisal of site formation processes highlights the fact that the archaeological assemblage is strongly time-averaged. We discuss these different results in the context of a recently rekindled interest in the so-called Pietersburg Industry.
\end{abstract}

We would like to dedicate this article to Revil Mason, who left us on the 13th of August 2020. Revil Mason discovered and excavated the site of Olieboomspoort and he performed the first descriptions of the lithic artefacts. His pioneering work on the prehistory of Limpopo remains a milestone in the history of the discipline and his insatiable curiosity for our past a source of inspiration for all of us.

This article is part of the Topical Collection on Settlement Patterns Dynamics of the Middle Paleolithic and Middle Stone Age

A. Val

aurore_val@yahoo.com

1 Abteilung für Ältere Urgeschichte und Quartärökologie, Universität Tübingen, Tübingen, Germany

2 Evolutionary Studies Institute, University of the Witwatersrand, 1 Jan Smuts Avenue, Johannesburg 2000, South Africa

3 Australian Research Centre for Human Evolution (ARCHE), Environmental Futures Research Institute, Griffith University, 170 Kessels Rd, Nathan, QLD 4111, Australia

4 Centro Nacional de Investigación sobre la Evolución Humana (CENIEH), Paseo Sierra de Atapuerca, 3, 09002 Burgos, Spain

5 Rock Art Research Institute, School of Geography, Archaeology and Environmental Studies, University of the Witwatersrand, Johannesburg, South Africa
6 GEM (Guías de Espeleología y Montaña), Casilla del Mortero, Torremocha del Jarama, 28189 Madrid, Spain

7 School of Geography, Archaeology and Environmental Studies, University of the Witwatersrand, 1 Jan Smuts Avenue, Johannesburg 2000, South Africa

8 Nordic Laboratory for Luminescence Dating, Department of Geoscience, Aarhus University, Aarhus, Denmark

9 Department of Anthropology and Archaeology, University of South Africa, Pretoria, South Africa

10 Radiogenic Isotope Facility, School of Earth and Environmental Sciences, The University of Queensland, Brisbane, QLD 4072, Australia 
Keywords Savanna Biome $\cdot$ Pietersburg Industry $\cdot$ Rock shelter archaeology $\cdot$ Site formation processes $\cdot$ Palaeoenvironments · Equus capensis

\section{Introduction}

In southern Africa, several coastal and near-coastal sites have provided evidence for the emergence of innovative behaviours amongst early modern human populations (e.g. Henshilwood et al. 2002, 2004, 2011; d'Errico et al. 2005, 2008, 2012; Marean et al. 2007; Backwell et al. 2008; Jacobs et al. 2008; Mourre et al. 2010; Texier et al. 2010, 2013; Wadley et al. 2011). Discoveries from Pinnacle Point, Diepkloof Rock Shelter, Blombos Cave, Klasies River Mouth and Sibudu Cave (Fig. 1) have led to a concentration of research along the western, southern and eastern shorelines of the tip of the African continent. These sites are unquestionably enriching our understanding of the complex network of factors behind the development, diffusion and disappearance of technological innovations and symbolic behaviours characteristic of human populations living in the coastal region of southern Africa. Nonetheless, when considered within the general framework of the emergence and dispersion of our species within and outside Africa, they represent only a single piece of the complex Late Pleistocene puzzle of human evolutionary history (e.g. Groucutt et al. 2015; Henn et al. 2018; Schlebusch and Jakobsson 2018; Will et al. 2019).

Southern Africa comprises a mosaic of biomes, including some typical of the African continent, such as the Savanna Biome, as well as biomes that are geographically restricted, in particular, the Mediterranean Fynbos Biome, where most of the coastal and near-coastal sites are found (one notable exception is Sibudu Cave located in the Indian Ocean Coastal Belt Biome). In the last few years, several researchers have

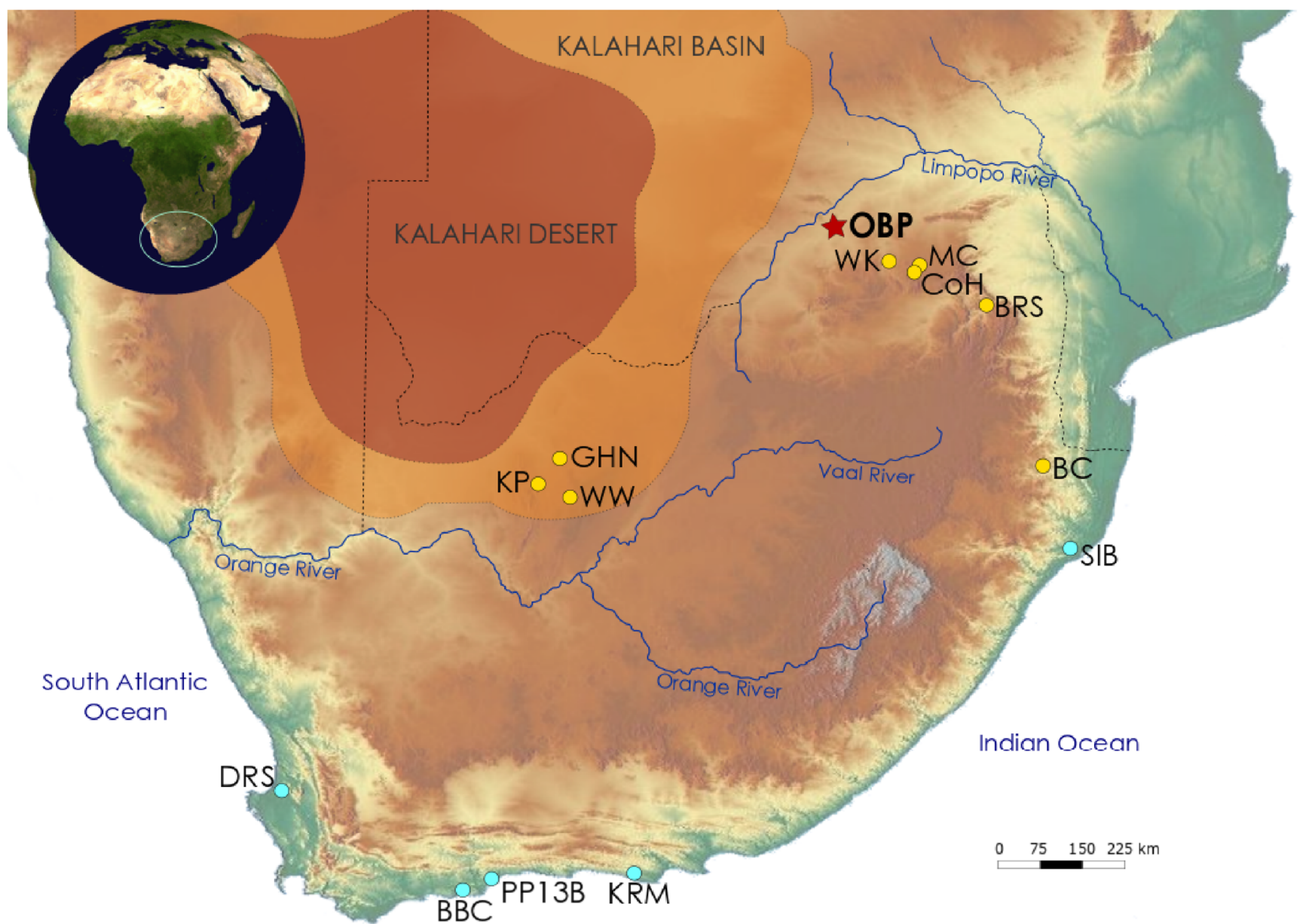

Fig. 1 Map of southern African showing the geographical location of Olieboomspoort (OBP) and several other MSA sites in the Savanna Biome mentioned in the text (yellow circles; BC: Border Cave, BRS: Bushman Rock Shelter, CoH: Cave of Hearths, GHN: Ga-Mohana Hill, KP: Kathu Pan, MC: Mwulu's Cave, WK: Wonderkrater, WW:
Wonderwerk Cave); and coastal and near-coastal Late Pleistocene MSA sites (blue circles; BBC: Blombos Cave, DRS: Diepkloof Rock Shelter, KRM: Klasies River Mouth, PP13B: Pinnacle Point Cave 13B, SIB: Sibudu) 
highlighted the relevance of examining Middle Stone Age (MSA) techno-cultural expressions in other parts of southern Africa and, specifically, of comparing data from the interior with data from the coast (e.g. Stewart et al. 2012; Backwell et al. 2014; Wurz et al. 2018; Ames et al. 2020; Wilkins et al. 2020). This notwithstanding, there is still a marked discrepancy between the degree of data resolution in terms of chronology, techno-cultural expressions, subsistence strategies and palaeoenvironmental context dedicated to Pleistocene human groups occupying the coastal regions, and similar data contemporaneous with human populations in the interior. The new field project at Olieboomspoort (OBP) represents one attempt to compensate for this discrepancy. A critical question relates to how much the climatic instability characteristic of the Middle to Late Pleistocene (e.g. Scott 1999; Scott and Neumann 2018) - i.e. the period associated with the emergence of our species and the development of the MSA technology - affected hominin populations living in the interior. Evaluating the impact of climatic changes on early modern human populations' subsistence strategies and technological choices requires that we expand our dataset on sites from the interior. This is particularly relevant in the case of Olieboomspoort, the focus of this paper, considering its proximity to the Kalahari Basin and the direct impact increased aridity might have had on the Waterberg mountainous massif (Fig. 1). Olieboomspoort is also one of a handful of South African sites preserving evidence for pulses of occupation during both the Earlier Stone Age (ESA) and the MSA, together with, for instance, Wonderwerk Cave and Cave of Hearths in the interior, and Montagu Cave in the Fynbos Biome (Keller 1973; Mason 1988; Chazan et al. 2008). The interior of South Africa witnesses the complex transition from ESA to MSA technologies and is home to the earliest occurrences of blade technology, prepared cores and the manufacture of unifacial points (McNabb and Beaumont 2012; Wilkins and Chazan 2012; Wilkins et al. 2012; Chazan et al. 2020). Far from being a simple 'backwater' region, where the MSA would have started to diffuse prior to the technological and cultural burgeoning of the Marine Isotopic Stages (MIS) 5 and 4 documented in the coastal region, the interior should be regarded as pivotal in understanding the emergence of early modern humans' behavioural plasticity (Stewart et al. 2012; Wadley 2015; Chazan et al. 2020).

Long-term research at sites such as Wonderwerk Cave and Kathu Pan sheds some light on these aspects, by integrating information on technological aspects (e.g. Wilkins and Chazan 2012; Chazan et al. 2020) within a regularly refined palaeoenvironmental framework (Lukich et al. 2020). Recent fieldwork conducted in the Savanna Biome, south of the Limpopo River, constitutes several parallel attempts to compensate for the limited knowledge regarding the nature of MSA developments in the interior of southern Africa. This notably includes fieldwork at Bushman Rock Shelter (Porraz et al. 2015, 2018), Mwulu's Cave (de la Peña et al. 2019), Steenbokfontein (Wadley et al. 2016), Wonderkrater (Backwell et al. 2014) and Ga-Mohana Hill North Rockshelter (Wilkins et al. 2020) (Fig. 1). It also includes fieldwork at Border Cave, further east (Backwell et al. 2018) and at Grassridge Rockshelter, today in the Highveld Grassland but close to the limit of the Sub-Escarpment Savanna (Ames et al. 2020). The Olieboomspoort project is part of this collective research effort. In order for the site to contribute to the characterisation of MSA cultural dynamics in the southern African interior, we first need to provide a robust chronological frame for the deposits and to investigate site formation processes. There is also need for more comprehensive palaeoclimatic and palaeoenvironmental reconstructions across the Savanna Biome during the Pleistocene (but see Scott 1999; Backwell et al. 2014; Chazan et al. 2020; Esteban et al. 2020), and the Olieboomspoort project aims to evaluate the potential of the site for palaeoenvironmental reconstructions using different organic proxies. Another motivation to reopen the site was to conduct a spatial investigation of synchronic or sub-synchronic sedimentary variations and, in the case of good preservation of archaeological deposits, to explore the utilisation of rock shelter spaces by humans. Previous excavations conducted by van der Ryst (2007) exposed a large $20 \mathrm{~m}^{2}$ sub-horizontal surface of MSA deposits. One of the goals of the fieldwork was to test the integrity of the archaeological deposits and the potential of the site for large-scale horizontal excavations.

\section{Description of the site}

Van der Ryst (2007) provided detailed site information; we present a brief summary here. Olieboomspoort $\left(23^{\circ} 52^{\prime} 42^{\prime \prime} \mathrm{S}\right.$; $^{\prime}$ $\left.27^{\circ} 38^{\prime} 17^{\prime \prime} \mathrm{E}\right)$ is one of the largest rock shelters in the Waterberg mountainous massif in northern Limpopo (Fig. 2).

While it is called 'Olieboompoort' by Mason $(1957,1959$, 1962, 1982), we follow van der Ryst (2007) and use the original name of 'Olieboomspoort' (hereafter referred to as 'OBP'). The shelter was named by the first European occupants of the region and is a contraction of two Afrikaans names. 'Olieboom-' refers either to the exotic castor oil bush (Ricinus communis) or to the thorn apple (Datura stramonium) and '-poort' refers to the deep channel cut into sandstones on an outside bend of the Riet Spruit forming a high, overhanging wall. OBP is located within a steep valley with altitudes varying between 800 and 950 m.a.s.l. (Fig. 2). The shelter is only a few metres away from a mostly perennial, south-flowing shallow watercourse, the Riet Spruit, a tributary of the Mokolo River (Fig. 3). The Mokolo River is one of the major rivers running across the Waterberg Plateau, which joins the Limpopo River some $80 \mathrm{~km}$ northeast of the site. The proximity of the shelter to the Riet Spruit (Fig. 3) implies 


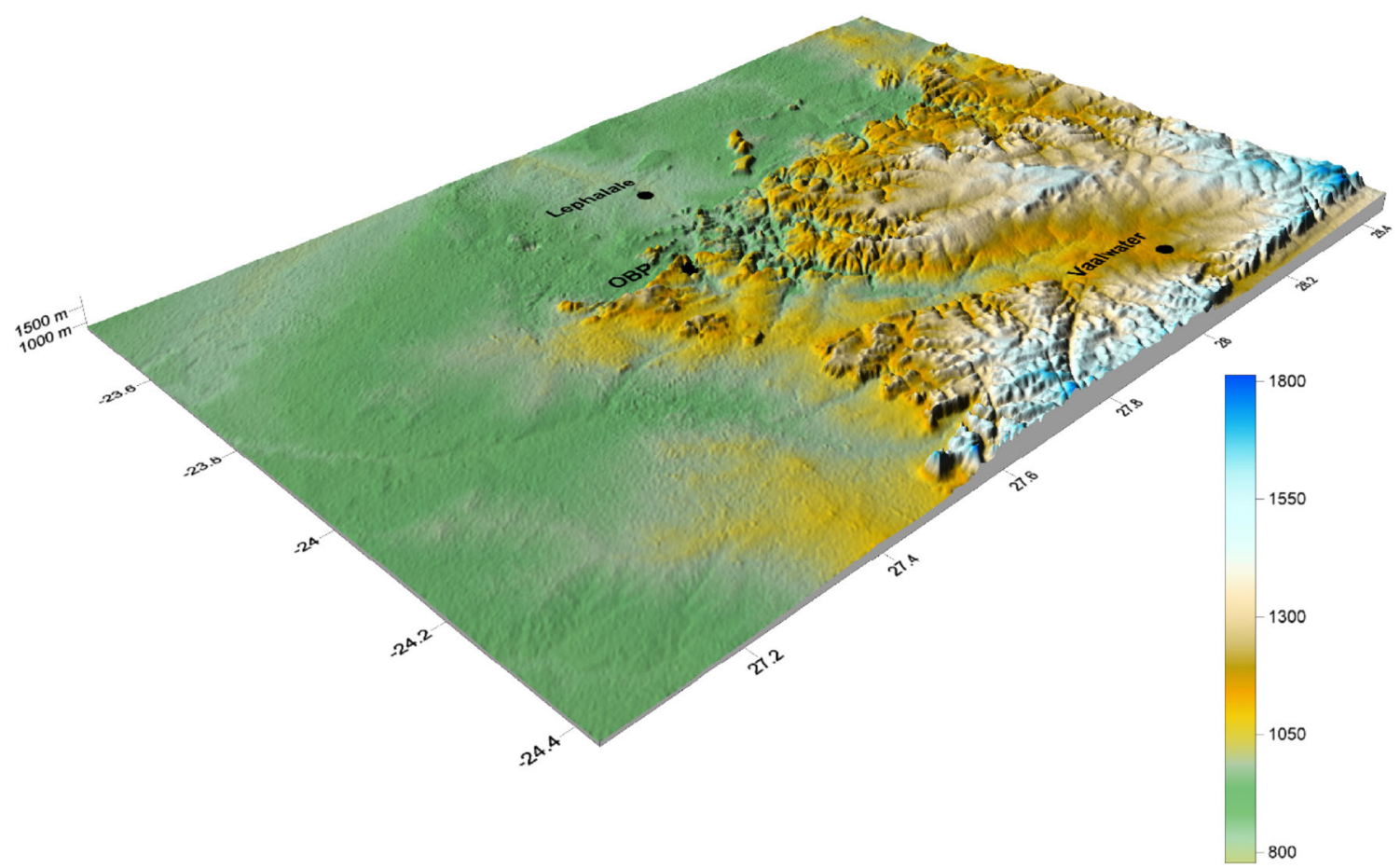

Fig. 2 Digital terrain model with geographical coordinates showing the position of Olieboomspoort on the northern fringe of the Waterberg massif, south of Lephalale and north-west of Vaalwater (image: F. Colino). The colour scale refers to altitude in metres above sea level.

that water likely played a significant role in both the site's attractiveness to human groups and in sedimentary processes.

OBP is a long, narrow shelter carved within the well-bedded Waterberg red sandstones, estimated to be between 1.9 and 1.7 billion years old (Eriksson et al. 2000). Specifically,
Digital terrain model retrieved from https://pdaac.usgs.gov/ maintained by the NASA EOSDIS Land Processes Distributed Active Archive Center (LP DAAC)

OBP is located within the Mogalakwena Formation that mostly comprises conglomerates, coarse to fine sandstones and shales (Brandl 1996). Locally available raw materials include cobbles of crypto-crystalline silicates (CCS) such as chert, jasper and other siliceous rocks that are abundant in the host
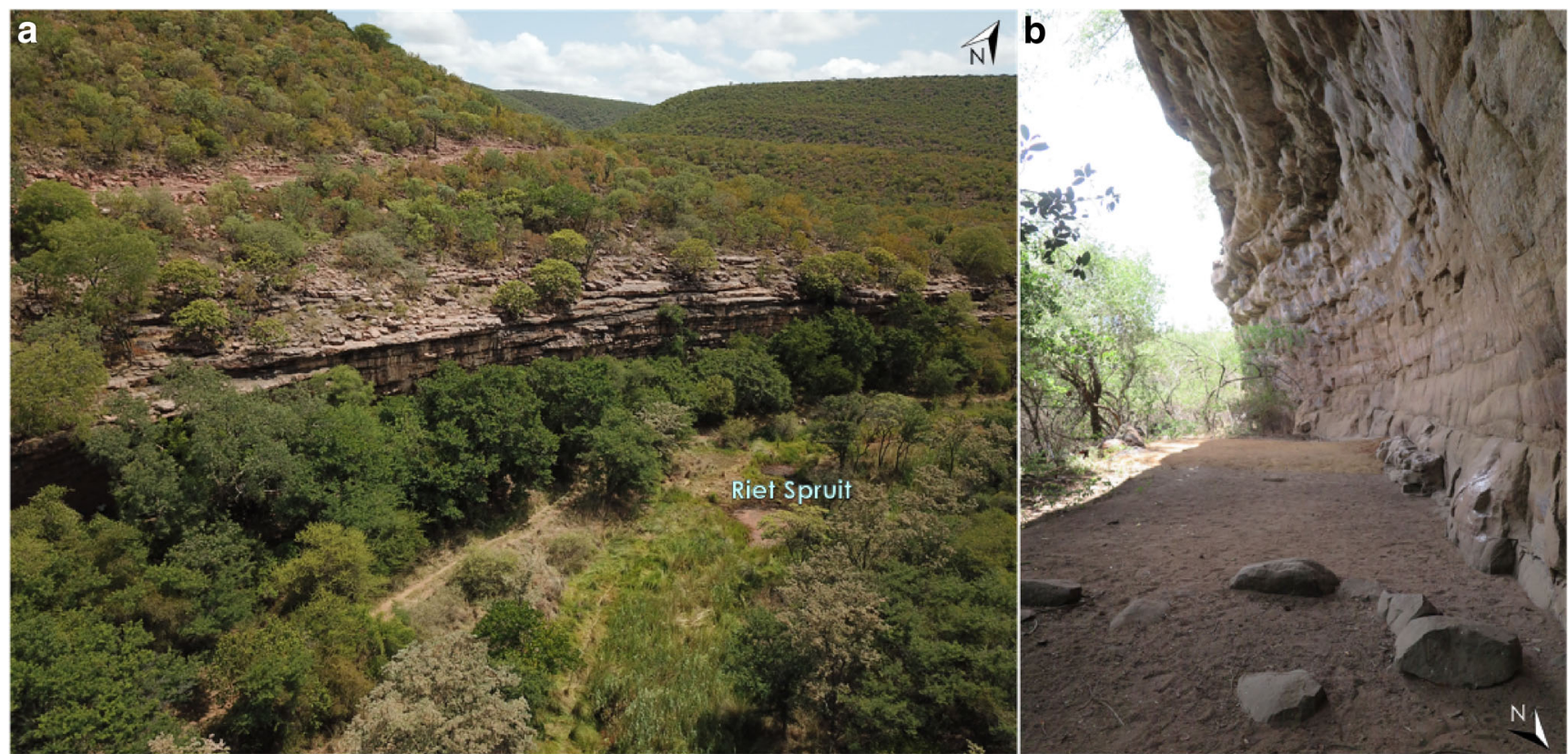

Fig. 3 a Drone picture of the cliff hosting Olieboomspoort, highlighting the proximity to the Riet Spruit as well as the dense vegetation cover in the summer (picture courtesy of S. Küsel). b General North view of the shelter in 2018 before reopening the site (picture D. Stratford) 
rock conglomerates; quartzite slabs and cobbles, abundant intrusive hydrothermal vein quartz (including quartz crystals); and locally abundant haematite and specularite (van der Ryst 2007). The sheltered area at OBP is estimated to be at least 70 $\mathrm{m}$ long with a maximum width under the overhang of $7 \mathrm{~m}$. Van der Ryst (2007) estimates the extent of preserved horizontal archaeological deposits to ca. $50 \mathrm{~m}^{2}$. The open, north to south concave morphology of the shelter indicates it formed initially through the erosion of the sandstones on the outside bend of the Riet Spruit. The varied lithology of the Mogalakwena Formation in the vicinity of the shelter mean that the processes of shelter breakdown, enlargement and autogenic sedimentation vary across space and time. Gradual weathering takes the form of small-scale exfoliation of sandstones particularly focused at bedding contacts, which produces small, angular, concave sandstone clasts and releases isolated included particles (sand to cobble size fluvial sediments) and minerals (calcite, heavy compounds such as haematite). Sporadic large-scale breakdown caused mostly by the preferential weathering of shale beds and gradual removal of support at the dripline produces larger clasts (up to boulder size) that are angular to sub-rounded and generally equant or tabular in shape. Collapse seems to be more rapid at the dripline where abundant and directly associated large clasts form a dripline talus potentially trapping sediments within the shelter and protecting deposits from a flooding river.

OBP falls within the Summer Rainfall Zone and experiences hot summers and mild winters with yearly temperatures ranging between -5 and $40^{\circ} \mathrm{C}$ and a peak of precipitation occurring in January. It is located in the Savanna Biome at the transition between the Limpopo Sweet Bushveld and the Waterberg Mountain Bushveld (Mucina and Rutherford 2006). The vegetation combines a ground layer dominated by $\mathrm{C} 4$ grasses with an upper woody layer comprising short bushveld species and more open savanna tree taxa. Common trees and shrubs in the Waterberg Mountain Bushveld are, amongst many others, Burkea africana, Croton spp.; Euclea crispa, Combretum spp.; and several Senegalia and Vachellia species (aka acacias), Faurea saligna and Olea capensis. The Limpopo Sweet Bushveld is characterised by acacia trees, Combretaceae, Dichrostachys cinerea, Grewia flava and Commiphora pyracanthoides (Mucina and Rutherford 2006). Poaceae and Asteraceae are widespread in both vegetation units, and other herbs are Commelina spp., Hibiscus meyeri and Tephrosia spp. (Mucina and Rutherford 2006).

\section{Previous archaeological work at Olieboomspoort}

OBP is one of the prominent sites featuring in Mason's work on the Stone Age in the former Transvaal (Mason 1957, 1962). Alongside other sites such as Mwulu's Cave,
Aasvoëlkop, Koedoesrand and the reference site Cave of Hearths, the rich lithic assemblage from OBP contributed to his definition of the Pietersburg Industry as well as to his interpretation of the ESA, MSA and Later Stone Age (LSA) succession in the former Transvaal region. During a week in 1954, Mason excavated a test-trench ca. $12 \mathrm{ft}$ long $(3.5 \mathrm{~m})$ at OBP (Mason 1962, Fig. 4). The lack of a clear stratigraphy led him to excavate in spits, until he reached a stony layer at about $2 \mathrm{~m}$ deep that he interpreted as the bedrock (R. Mason pers. comm. 2018). Despite the relatively limited size of the excavation (Fig. 4), it yielded a rich lithic assemblage, with more than 1350 artefacts of 'primary classes' (these 'primary classes' refer to flake classes and include quadrilateral, triangular and irregular flakes; Mason 1957: p.122) and 145 cores (Mason 1957, 1962). Raw materials identified by Mason include felsite, quartzite, mudstone, chalcedonies, quartz and other CCS. Mason does not mention faunal remains but he notes that 'at sites like Olieboompoort or the Cave of Hearths similar people [to those from Kalkbank] lived close to excellent supplies of tool-making rocks and appear to have ignored bone as raw material' (Mason 1962: p.250). Mason collected ochre remains, including crayon-shaped pieces. He writes that 'Transvaal Middle Stone Age people knew about colour and used it for painting red or yellow designs on their bodies, for at some sites like Olieboompoort we found hundreds of haematite fragments, including many that show signs of being rubbed for reddish powder' (Mason 1962: p.236). Still referring to the MSA, he mentions elsewhere: 'a remarkable mass of haematite and ochre fragments occurs in Olieboompoort 2, again with grindstones' (Mason 1962: p.273). The OBP MSA ochre assemblage is different from other MSA assemblages in terms of both raw material types - heavy, hard specularite or haematite - and comparatively rare cases of use-wear (Watts 1998, 2002). Ian Watts suggested that the site potentially functioned as a 'factory site', or primary processing site, for locally procured specular haematite 'with some of the product being transported, possibly in a regional exchange network' (Watts 1998: p.706). There is no established evidence of such a network, but further research into possible sources and ochre activities at the site would help to ascertain if this explains the unusual nature of the OBP ochre assemblage.

A second phase of investigation, with a primary interest in the Holocene layers, took place at the site almost 50 years later, led by M. van der Ryst (van der Ryst 2007). In 1997, she excavated a $1 \times 5 \mathrm{~m}$ test-trench a couple of metres away from Mason's trench to clarify the general stratigraphy and, like Mason, reached a stony basal layer at ca. $2 \mathrm{~m}$, which she interpreted as the bedrock. A larger excavation area was then opened, $1 \mathrm{~m}$ away from the test-trench with the aim of further investigating the LSA occupations and extending the archaeological sample size. Twenty square metres, labelled A to D from southwest to northeast and numbered one to five from southeast to northwest, were excavated during a subsequent 


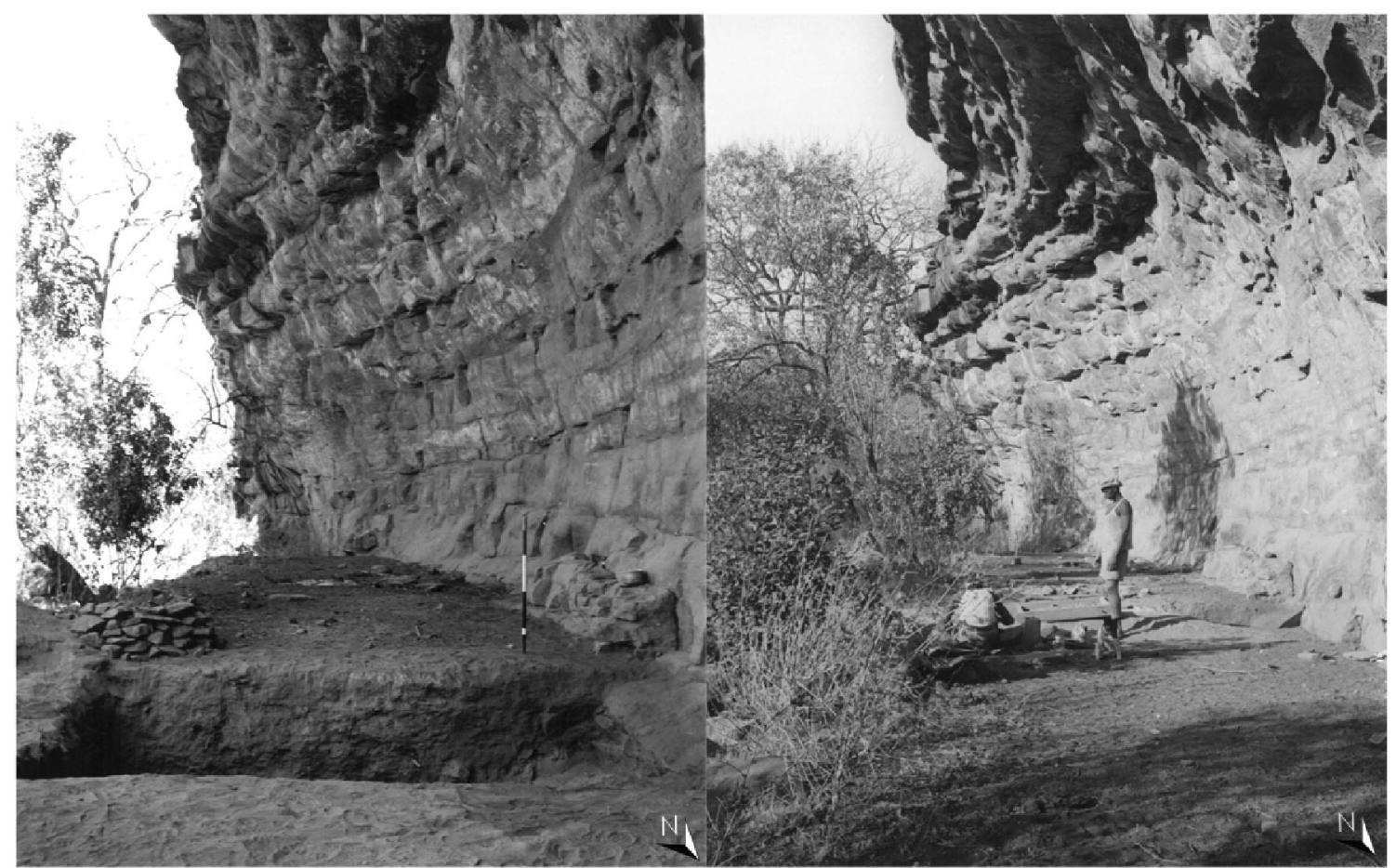

Fig. 4 Mason's excavation at Olieboomspoort in 1954. Left: general north view of the test-trench towards the end of the excavation. Right: two workers sorting next to the test-trench (pictures courtesy of the Wits Archaeology Collection)

six fieldwork campaigns (Figs. 5 and 6). The lack of stratigraphy, already noted by Mason (1962), is also observed by van der Ryst, who highlights the 'relative homogeneous nature of the deposits' and the fact that 'the natural stratigraphy [was] extremely difficult to define' (van der Ryst 2007: 5960). Her excavation therefore proceeded in $5 \mathrm{~cm}$ spits for a depth of $1 \mathrm{~m}$ until 'the interface between the LSA and MSA occupational levels was satisfactorily established' (van der Ryst 2007: p.46). This interface was characterised by an important spalling event (van der Ryst 2007: p.56). Spalling events consistent with significant occupation hiatuses between the MSA and the LSA are documented elsewhere in the interior of the southern African region: at Bushman Rock Shelter in Limpopo Province (Butzer 1984; Badenhorst and Plug 2012), and at Inyanga (Robinson 1958), Pomongwe and Tshangula (Cooke 1963), Redcliff (Brain and Cooke 1967) and Zombepata (Cooke 1971) in Zimbabwe. Similar spalling events tentatively linked to periglacial conditions have been noted in several Late Pleistocene sequences from the Lesotho Highlands, including Melikane, Ha Soloja and Sehonghong (Carter 1976; Mitchell 1996; Stewart et al. 2012).
Fig. 5 Northern view of the main area excavated by van der Ryst, towards the interface between the LSA and MSA layers. Note the clear gradient in roof spall density from the talus to the wall of the shelter (picture van der Ryst 2007)

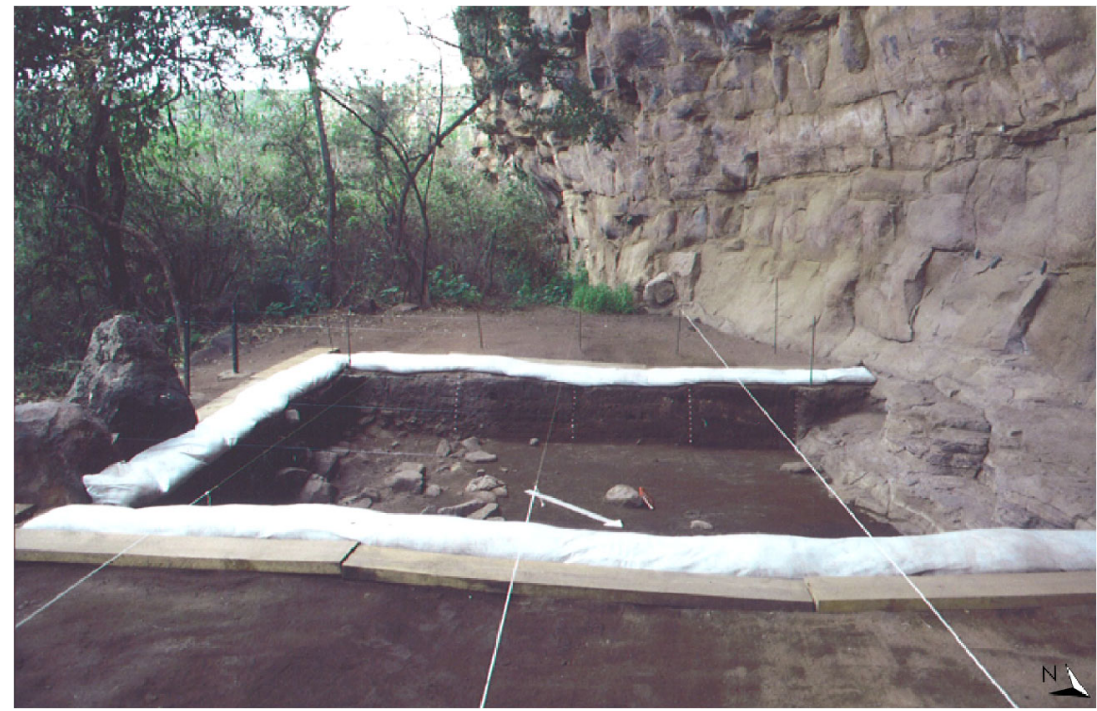




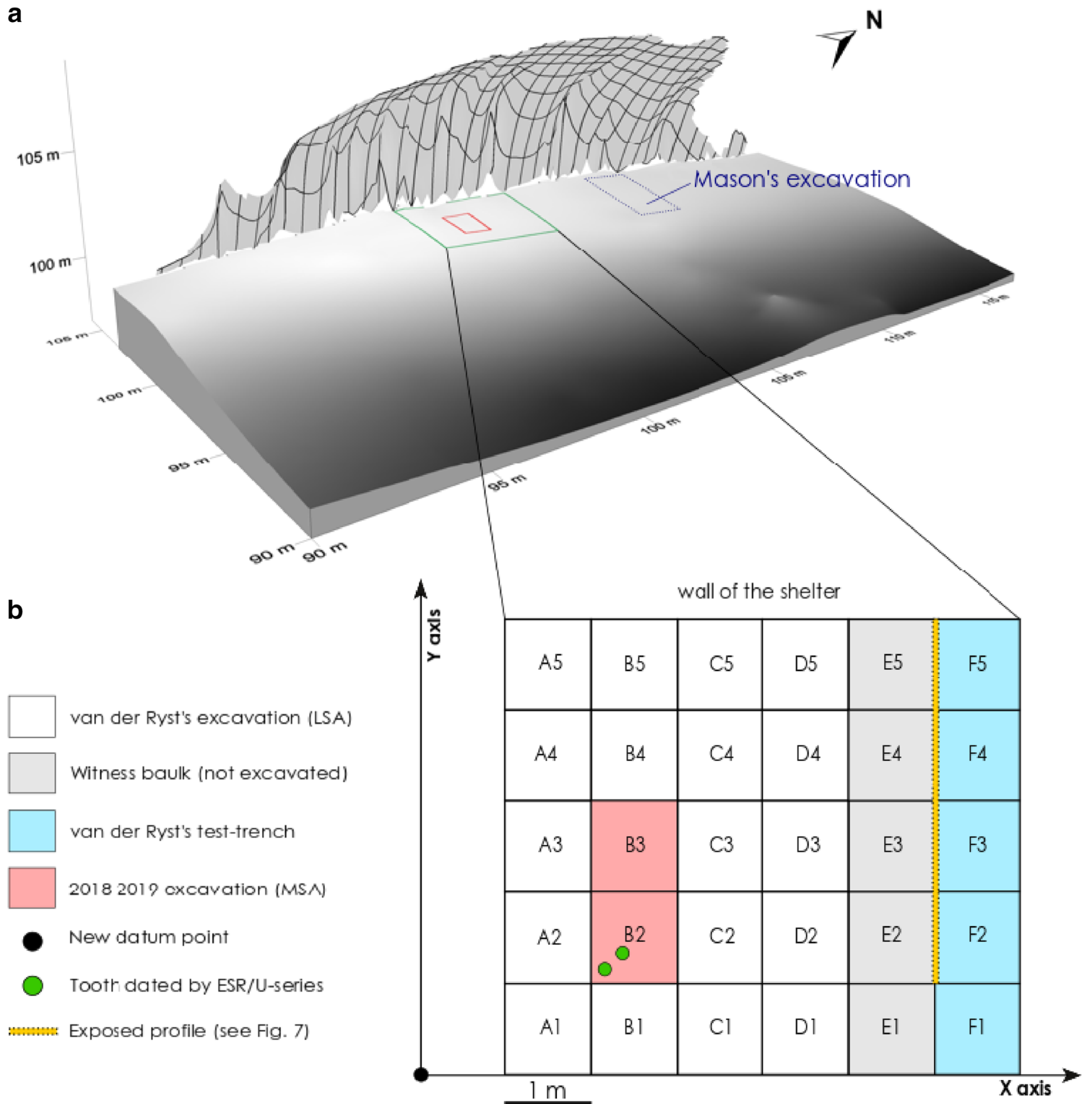

Fig. 6 (A) Topography of the rock shelter with the putative location of Mason's excavation, the excavation conducted by Maria van der Ryst inside the green square and the 2018-2019 excavation inside the red

The test-trench and the main excavation area were carefully backfilled and protected upon completion of the project.

Available information regarding site formation processes from these earlier campaigns is provided by van der Ryst (2007). While it concerns primarily the Holocene deposits, several key processes are likely to have played a similar role during the earlier phases, particularly autogenic sedimentary inputs from the surrounding shelter roof and walls and square (image: F. Colino). (B) Close-up on the excavation area showing the provenience of the two equid teeth dated by ESR/U-series as well as the profile illustrated in Fig. 7.

allogenic inputs from animal, meteoric and alluvial sources. Rainwater seems to have created a lag deposit beneath the dripline and percolating water and leaching calcium carbonates resulted in the encrustation of faunal and clastic remains in the area closer to the talus. Abundant plant growth at the dripline and extending down to the river valley has also facilitated widespread bioturbation and encouraged use of the shelter by animals. In the Holocene deposits, a combination of 
these natural processes with anthropogenic activities related to fire use and discard of lithics and animal remains seems to explain the sedimentary variation observed from the dripline talus to the wall of the shelter. Close to the talus, underneath the dripline, sediments are composed of a stony matrix; they are coarse and humic, while they become much drier towards the wall and consist of almost pure ash. In parallel, important quantities of lithics, haematite, larger faunal remains and pieces of ceramics were recovered towards the talus while higher concentrations of organic remains linked to the much drier ashy sediments related to fire activities were retrieved against the wall. Finally, modern bioturbation in the form of small rodent burrowing and insect (dung beetles and termites) activities is noted in between excavation campaigns by van der Ryst (2007).

\section{The chrono-cultural sequence}

At the bottom of the sequence, consistent with Mason's Bed 1 and the base of van der Ryst's test-trench, previous excavations recovered a few Acheulean tools. These tools were mixed with the abundant rocks constitutive of the basal layer, directly on top of what both Mason and van der Ryst considered as the bedrock (van der Ryst 2007). Mason mentions several examples of ESA bifaces, which he attributed to a 'probably Later Acheul Culture' (Mason 1962: p.74). During van der Ryst's excavation, a handaxe and a cleaver, both made of sandstone, were retrieved (van der Ryst 2007). While these tools were not found associated with a clear occupational layer and remain undated, they document visits to the area by hominins at least as far back as the Middle Pleistocene. The limited size of the assemblage, combined with the absence of chronology and recent techno-typological appraisal of the OBP ESA lithic assemblage, likely explains why syntheses on the southern African Acheulean rarely mention the site (e.g. Lotter and Kuman 2018; but see Kuman 2016). We hope to tackle this issue in the framework of this project. We provide the first description of the ESA tools from Mason's excavation in the results section.

The high density of MSA artefacts, recovered over an area of several square metres from the north-eastern extremity of Mason's trench until the south-western extremity of van der Ryst's main excavation area and to a depth of $1 \mathrm{~m}$ in both testtrenches, indicates the intensive and/or repeated use of the shelter over a long time. Mason attributed the MSA layers (Bed 2) to his middle stage of the Pietersburg Industry, corresponding to the lithic industry from Cave of Hearth's Bed 5. Radiocarbon dating for OBP Bed 2 was attempted at the British Museum Research Laboratory but the age obtained, greater than 33000 uncal. BP, fell beyond the range of the method (Mason 1962). Interestingly, this date, produced in
1955, represented the 'first indication of the great age of African Middle Stone Age’ (Mason 1982, p.135).

The upper part of the sequence represents about $1 \mathrm{~m}$ of deposits, which Mason (1962) subdivided into a thick unit (Bed 3), radiocarbon dated to $870 \pm 150 \mathrm{BP}$ and attributed to a Late Smithfield, and an undated Iron Age surface layer (Bed 4). Reinvestigation of the site underlines the complexity of the Holocene occupations, most likely associated with LSA hunter-gatherers during the contact period with groups of herders and Iron Age farmers moving into the Waterberg area. Van der Ryst (2007) attributes the lithic assemblage, characterised by formal microliths mostly made on crystal quartz and CCS, to the Classic Wilton, while Bambata ceramic sherds are present in most layers. A series of 25 radiocarbon dates place these LSA occupations between cal. $400 \mathrm{BC}$ and AD 900 (van der Ryst 2007; Appendix L). These complex interactions between hunter-gatherers, farmers and herders in the first millennium $\mathrm{AD}$ are indicated by the rock paintings at the site.

\section{The rock art inside the shelter}

OBP is a key site for the comprehensive assessment and understanding of rock art in the Waterberg region. The shelter walls are densely painted, but much of the imagery is poorly preserved: flaking, mineral crusts, dust and graffiti make many of the paintings difficult to see. Fire spalling has also damaged some of the lowermost paintings (van der Ryst 2007: p.229). The earlier fine-line paintings have mostly faded and are generally indiscernible, while the more recent and betterpreserved images - of which handprints are numerically significant - characterise the site (van der Ryst 2007: p.228).

Van der Ryst (2007) previously identified major rock art categories across the shelter. She noted that the motifs in the rock art sequence at OBP fit well within the general regional scheme of a threefold authorship pattern (Hall and Smith 2000; Eastwood 2003; Ouzman and Smith 2004; Eastwood and Smith 2005), pointing to complex inter-relationships over time at the same place. Older and poorly preserved red (San) hunter-gatherer paintings generally underlie the relatively more recent rock art assigned to (Khoekhoe) herders: these strikingly different geometric finger paintings range from red and orange to white, and show temporal overlaps with the former group (van der Ryst 2007: p.229). Other herder motifs at OBP include 'loincloths, aprons and handprints in red and yellow' (van der Ryst 2007: pp.229, 231, Appendix M: figs. 1-3). Last in the regional sequence is the so-called 'late white' African farmer 'rock art typical of Bantu-speaking people and linked to northern Sotho-speakers in the region' (van der Ryst 2007: p.229, Appendix M: figs. 4-5). A noteworthy set of images at OBP assigned to farmers is found in one of the largest panels: a procession of three large white ground birds 
of indeterminate species (van der Ryst 2007: p.232, Appendix M: fig. 5). In 2001, some of the clearest images were traced and redrawn in collaboration with the Rock Art Research Institute at the University of the Witwatersrand (van der Ryst 2007: Appendix M; OBP is indexed as RSA FAC1 in the archives of the Rock Art Research Institute).

From a single glance at the shelter, it is clear that handprints are the central motifs. The overall quantities and the intentional placement of the rock art may signify the special meanings that people attributed to OBP (van der Ryst 2007: p.12). As formal and contextual analyses of the rock paintings fell outside the scope of van der Ryst's (2007) research project, an indepth analysis is still needed. Ultimately, the importance of OBP's rock art lies in its ability to attest to the complex interactive history of the region (van der Ryst 2007: p.233).

\section{Preliminary results from recent field work at Olieboomspoort}

\section{Field activities}

We completed three main tasks during our 2018 and 2019 campaigns: (1) reopening van der Ryst's main excavation area (Fig. 6); (2) conducting a small-scale excavation in this main area to collect an initial sample of in situ MSA material and investigate the potential of the site for larger scale excavations; and (3) reopening van der Ryst's test-trench for dating purpose, as well as archaeobotanical and geoarchaeological analyses. As mentioned above, the previous excavation was carefully backfilled and relevant field information was available, which rendered the relocating and reopening of both the main excavation area and the test-trench easy. Inside the main excavation area, we kept the same square numbering system and decided to open $2 \mathrm{~m}^{2}$ (B2 and B3) for new test excavations. We excavated 20 décapages (i.e. smallest excavation unit consistent with an archaeological surface and defined by the base of archaeological material) in a first sedimentary unit and 10 in a second unit. The first unit (grey-sediment or GS) is characterised by a greyish and soft matrix with medium to large clasts. The second unit (yellow-reddish-sand or YRS) is characterised by reddish, coarser and mostly clast-supported sediment. We collected two fossil teeth from the first unit GS for combined U-series and electron spin resonance (ESR) dating purpose. Additionally, we reopened four of the $5 \mathrm{~m}$ of the test-trench (from F5 against the wall to F2 towards the talus; Fig. 6). We cleaned, photographed, drew and sampled the southern profile for optically stimulated luminescence (OSL) dating (in progress) and micromorphological blocks.

We also sampled sediment from the southern wall of the test-trench for pollen and phytoliths, along a 1-m line, starting from the surface. Most pollen and phytolith samples come from the Holocene LSA deposits and, due to the softness of the sediments, sampling was only possible every ca. $6 \mathrm{~cm}$. Sampling into the MSA deposits proved extremely difficult since the matrix is almost entirely clast-supported and contains little fine sediment; consequently, we took only two samples. We chose seven sediment samples (depths 10, 26, 40, 64, 76, 90 and $100 \mathrm{~cm}$ ) for initial testing of pollen and phytolith content. Samples were prepared for pollen analysis by using standard laboratory methods $(\mathrm{HF}, \mathrm{HCl}, \mathrm{KOH})$ and heavy liquid separation $\left(\mathrm{ZnCl}_{2}\right)$. Residues were mounted in glycerine jelly on glass slides for light microscopic examination. Phytolith morphotypes were extracted following standard procedures described in Piperno (2006). The procedure involved treating approximately $2-3 \mathrm{~g}$ of sediment with $10 \%$ hydrochloric acid in a hot water bath at $70^{\circ} \mathrm{C}$ to remove carbonates, then washing in distilled water by centrifuging and decanting. Organic matter was removed from the samples by adding concentrated nitric acid and placing in a hot water bath at $70^{\circ} \mathrm{C}$. Density separation of phytoliths was achieved by adding $5 \mathrm{ml}$ of sodium polytungstate solution at $2.4 \mathrm{~g} / \mathrm{ml}$ density. Phytoliths were mounted on microscope slides using glycerol and observed under $\times 400$ magnification using a Zeiss $\mathrm{CP}$-achromat light microscope mounted with a camera to identify phytoliths.

\section{Site formation processes and stratigraphy}

The large size, relatively open morphology and proximity of the shelter to the river mean that a potentially wide range of site formation processes has been active during and after deposition of the cultural and non-cultural deposits. The profiles exposed through the recent work at the site, particularly through the row $F$ test-trench (Fig. 7), reveal sedimentary facies and depositional features indicative of a broad suite of formation processes. Multiscale analyses are ongoing and so only initial observations are shared here.

Geogenic processes include numerous influences of the nearby river. Significantly, the complete sequence to the floor of the shelter is not yet exposed. Sporadic major collapse and smaller continual breakdown of the shelter roof and wall are evident and are described above and by van der Ryst (2007). It is interesting to note that the particles released from the host rock are fluvial in character; consequently, separating contemporary fluvial from ancient fluvial particles to understand proportional contribution of autogenic and allogenic sediments is not straightforward. At the western end of the test-trench (closest to the dripline), a mixture of fluvially derived cobbles, intermingled with cobble to boulder-sized angular to sub-rounded roof spalls, are present as a large, partially calcified talus.

Biogenic (including anthropogenic) processes are numerous and include mechanical and chemical accumulation and modification of cultural and non-cultural materials. The proximity of the river, well-vegetated shelter fringes and the general accessibility of the shelter mean that a wide range of 


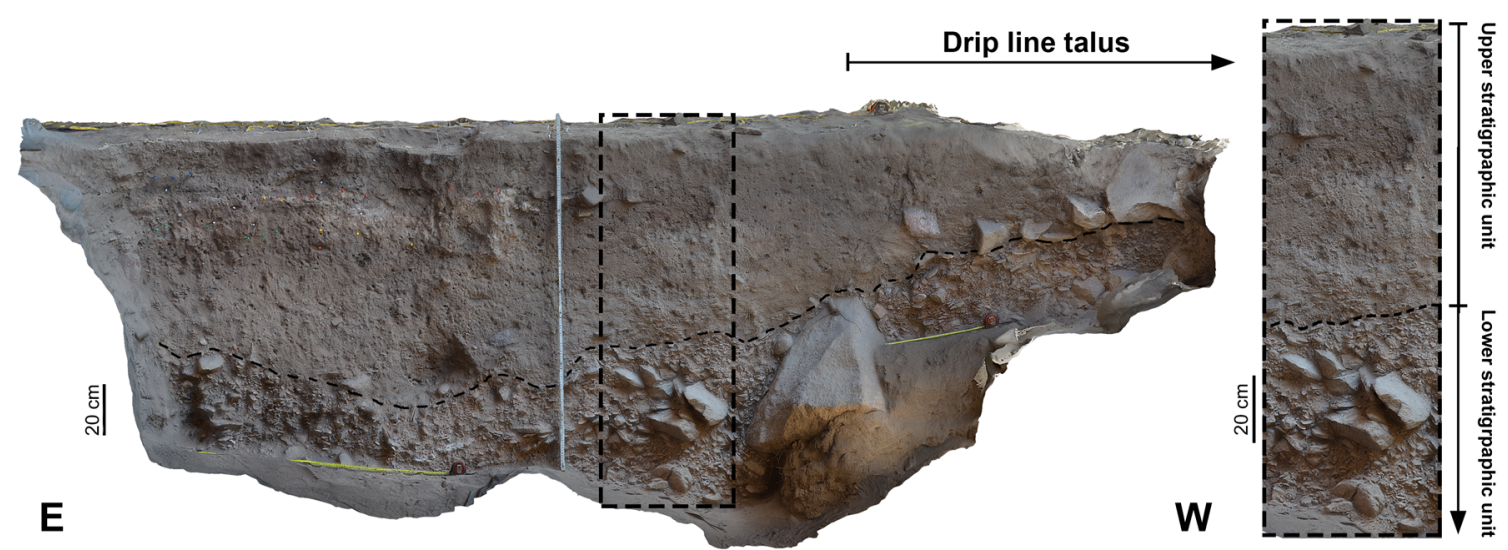

Fig. 7 Photogrammetric model of the exposed northern profile (row F) of the test-trench and a representative stratigraphic section (right; expanded from dashed rectangle on the profile) presenting features described in the

animals and plants have occupied the space. Bioturbation through root growth, trampling and burrowing is evident in the sedimentary features and fabric and has likely modified and dispersed cultural remains in at least the upper $50 \mathrm{~cm}$ of the sequence, making discrete and well-preserved archaeological features rare. Most of the visible, preserved features in this part of the sequence are ash packets, which have been hardened through calcification, and thus were afforded some protection from these processes.

In addition, we expect biochemical contributions to have significantly affected the preservation of organic remains. Thick layers of baboon and hyrax faeces removed during initial preparation of the site for excavation and intensive urine staining of the walls and floor in unexcavated areas attest to this likelihood. Accessibility to water, wood and abundant raw materials associated with the fluvial deposits and rock shelter lithologies provided a potentially comfortable occupation space for humans that increased the likely impact of primary and secondary anthropogenic mechanical (e.g. digging, sweeping, trampling) and chemical (e.g. burning, cooking, ochre processing) processes. The nature and extent of these will be clarified in our ongoing study.

We recognise two major sedimentary units in the exposed profiles of the test-trench (Fig. 7). The upper unit is equivalent to Mason's culturally identified Beds 3 and 4. The lower one is equivalent to Mason's culturally identified Bed 2 and includes the two stratigraphic units identified in squares B2 and B3. It must be noted that although there is a stratigraphic distinction between Mason's Bed 2 and his upper Beds (3 and 4), stratigraphic distinction between Beds 3 and 4 is not yet observed. The major upper and lower units are described below and are the subject of a more detailed ongoing micromorphological and sedimentological study.

In the upper unit, matrix-supported sediments associated with the LSA and Iron Age (Mason's Beds 3 and 4 respectively), comprise well-sorted, stratified and graded packages text. The dotted line illustrates the contact between the upper (Later Stone Age) and lower (Middle Stone Age) stratigraphic units on the representative profile (photographs and photogrammetric model D. Stratford)

with eroded upper surfaces that suggest both the depositional and erosive influence of water. Discrete channels are not evident but very faint cross-bedding may be present (to be clarified through micromorphology). Sediments are generally very loose, sandy to silty sand (ashy sand) in texture and locally homogenised by bioturbation from roots and burrows. Occasional isolated remnants of combustion features are present; they comprise ash, charcoal and rubified sediments. At the eastern end of the test-trench, localised calcite precipitation has protected some archaeological features and water moving against the wall and through the nearby sediments has caused localised deformation of strata. Clasts are infrequent and generally isolated, small, angular to sub-rounded and chaotically organised. Only in one central area of the profile in the upper $10 \mathrm{~cm}$ are several clasts found at a similar stratigraphic level, suggesting a discrete period of collapse or emplacement. Diffused grey patches of ash-rich sediments may represent dispersed combustion features. Modern faecal matter is present in the upper $30 \mathrm{~cm}$ of the profile. Exposed roots extend from the dripline back to the shelter wall and follow the gently concave W-E sloping upper strata that have formed over the underlying clast-supported unit and dripline talus. A relatively sharp $(5 \mathrm{~cm})$ unconformity divides the lower and upper sedimentary units in the exposed profile (Fig. 7), indicating an erosive event, possibly a significant hiatus in deposition and a change in the sedimentation rate and process. At the western end of the test-trench, larger, sub-angular clasts rest directly on the surface of the lower unit and are buried by upper unit sediments, suggesting a period of collapse at the dripline at the very end of the lower unit's deposition.

The lower stratigraphic unit (Mason's Bed 2) has a gently concave W-E sloping surface and is predominantly clast-supported, artefact-bearing and partially but variably calcified. The matrix of this unit varies across the exposure but is generally sandy to silty sand in texture. Within this unit, clasts are generally poorly sorted and vary in size and shape from 
Table 1 Technological composition of the lithic assemblage from the 2018 excavation at Olieboomspoort, from units GS and YRS

\begin{tabular}{lll}
\hline Category & $N$ & $\%$ \\
\hline Levallois flake & 19 & 40.4 \\
Débordant flake & 4 & 8.5 \\
Natural backed knife & 1 & 2.1 \\
Trapezoidal section blade & 2 & 4.3 \\
Pseudo-Levallois flake (unretouched) & 5 & 10.6 \\
Levallois point (unretouched) & 15 & 31.9 \\
Blade $>$ 10-cm breadth & 1 & 2.1 \\
Total & 47 & 100 \\
\hline
\end{tabular}

boulders, large cobbles and angular blocks $(>10 \mathrm{~cm})$ near the dripline talus to medium and small angular to sub-rounded clasts with less frequent cobble presence in the central and eastern portions of the profile. Although some lateral grading is present, isolated larger clasts are found across the unit. Some internal stratification, indicated by packages of different clast sizes, is present and more evident close to the talus where a potential sequence of oscillating rates of shelter breakdown and alluvial accumulation are preserved. Larger clasts are generally sub-rounded in shape with occasional inclusions of very rounded river cobbles. Smaller clasts are more angular to subrounded and artefacts in the upper portions of the lower unit are very fresh. Clasts visible in the deepest exposures in the profile are larger and tabular with rounded edges (potentially attributable to Mason's Bed 1), with powdery or exfoliated weathered surfaces and are occasionally surrounded by coarse particles, suggesting in situ weathering due to periodic saturation by water. Clasts are often directly associated, especially in the western end of the profile, close to the talus, where active winnowing has locally deflated and deformed the deposits. Significant deformation occurs close to large boulders and clasts. Here, smaller particles are deflated down onto and around the clasts with fabrics conforming closely to the upper surface topography of the boulder. Despite localised

\begin{tabular}{|c|c|c|c|}
\hline \multirow{10}{*}{$\begin{array}{l}\text { Table } 2 \text { Types and } \\
\text { frequency of cores } \\
\text { present in the lithic } \\
\text { assemblage from the } \\
2018 \text { excavation at } \\
\text { Olieboomspoort, from } \\
\text { units GS and YRS }\end{array}$} & Core type & $N$ & $\%$ \\
\hline & Levallois & 4 & 20 \\
\hline & Bipolar & 3 & 15 \\
\hline & Discoidal & 2 & 10 \\
\hline & Tested & 2 & 10 \\
\hline & Core on flake & 1 & 5 \\
\hline & Bladelet core & 2 & 10 \\
\hline & Burin-like core & 1 & 5 \\
\hline & Indeterminate & 5 & 25 \\
\hline & Total & 20 & 100 \\
\hline
\end{tabular}

Table 3 Type and frequency of retouched pieces in the lithic assemblage from the 2018 excavation at Olieboomspoort, from units GS and YRS

\begin{tabular}{lll}
\hline Category & $N$ & $\%$ \\
\hline Bifacial piece & 1 & 1.6 \\
Retouched flake & 16 & 25 \\
Retouched blade & 3 & 4.7 \\
Notch & 3 & 4.7 \\
Denticulate & 7 & 10.9 \\
Denticulate point & 3 & 4.7 \\
End-scraper & 9 & 14.1 \\
Double end-scraper & 2 & 3.1 \\
Burin & 1 & 1.6 \\
Retouched Levallois point & 8 & 12.5 \\
Retouched pseudo-Levallois & 6 & 9.4 \\
Indeterminate & 5 & 7.8 \\
Total & 64 & 100 \\
\hline
\end{tabular}

deformation (more frequently found near the surface of the deposits and close to the dripline), clasts generally retain a planar fabric with a gentle W-E slope at the dripline flattening in the centre with a gentle E-W slope at the shelter wall (to be confirmed through dedicated fabric analysis documented during the excavation). Deeper in the exposed profile of the lower unit, clast fabric seems to be more horizontal, suggesting preferential accumulation and deflation of clasts at the dripline facilitating the development of the concave morphology of the deposit. Localised calcification of the deposits is focused near the dripline talus and extends to the central portion of the profile. Calcification appears to have originated from dripwater percolating through the deposit with 1-3-mm thick crusts comprising $<2$-mm particles forming on the upper surfaces of clasts and artefacts. Removal of these crusts reveals a mixture of well-preserved and weathered upper surfaces. The upper $10-15 \mathrm{~cm}$ of the eastern portion of the unit is heavily cemented. The upper limits of the same deposit have been exposed in squares B2 and B3 and reveal a generally chaotic fabric (perhaps with remnant planar organisation) and cementation by abundant calcite precipitation.

The lower, clast-supported, artefact-bearing unit has clearly been subjected to mechanical and chemical processes during and after its accumulation, forming a potentially significantly time-averaged unit. Processes seem to have been limited in energy in initial deposition but include local and non-local sources of sediment. The calcification of the deposit has aided retention of small flaking debris in the upper parts of the unit, but this debris material may have been vertically mobilised (and so is not necessarily contemporaneous with the tools) and may be missing from lower and more central areas of the site. The freshness of the artefacts is suggestive of limited 


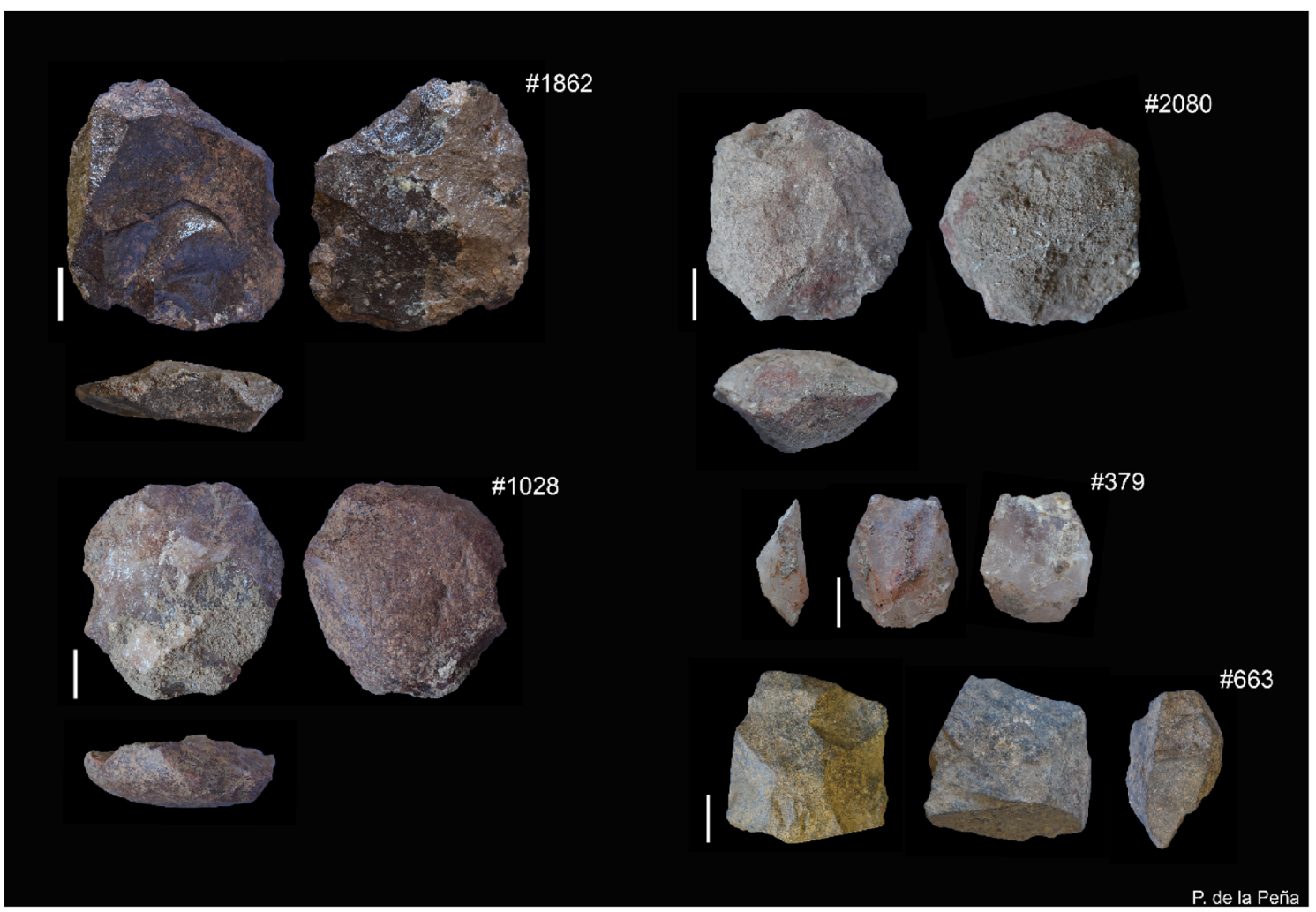

Fig. 8 MSA Levallois cores (pieces \#1862, \#1028 and \#2080) from the 2018 excavation at Olieboomspoort. The last scar of \#1862 could correspond to a triangular blank, which are abundant in the lithic assemblage. \#379: freehand-knapped crystal quartz. \#663: core on flake with burin-like bladelet reduction on one of the sides of the flake. All scales are $1 \mathrm{~cm}$ (pictures P. de la Peña) movement of at least some artefacts, although it remains to be seen if the artefacts at the base of the current profile are modified by transport or in situ decay (or both). It is probable, given the proximity of the river, that flooding and base-level fluctuations have aided in the submersion, weathering and deflation of the lower units from below, while rain and calcium-enriched dripwater have aided deflation and calcification from above.

Despite the lack of good contextual information, OBP is often cited as representing a rare example of a stratified ESA-

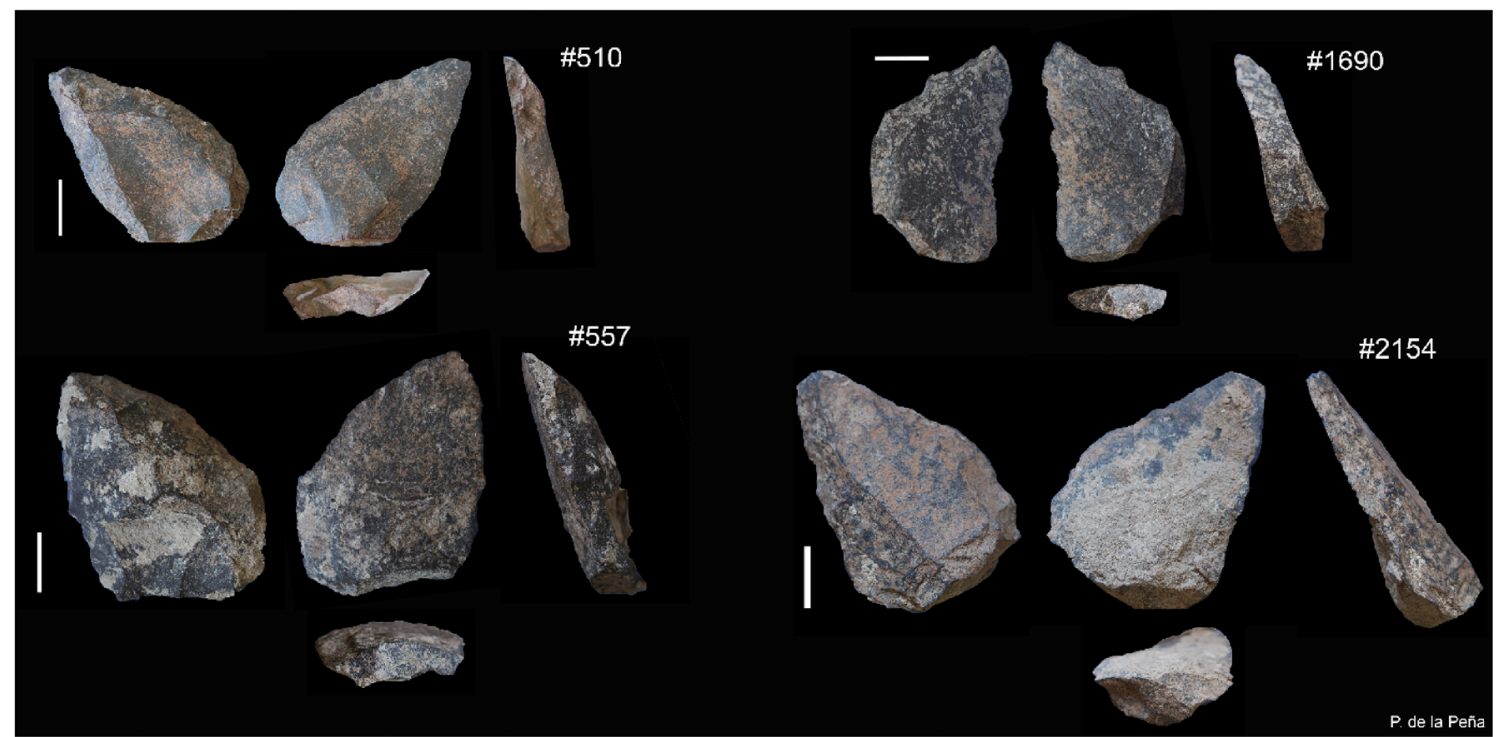

Fig. 9 MSA retouched pseudo-Levallois points from the 2018 excavation at Olieboomspoort. All scales are $1 \mathrm{~cm}$ and all pieces are orientated with the platform down and flat (pictures P. de la Peña) 


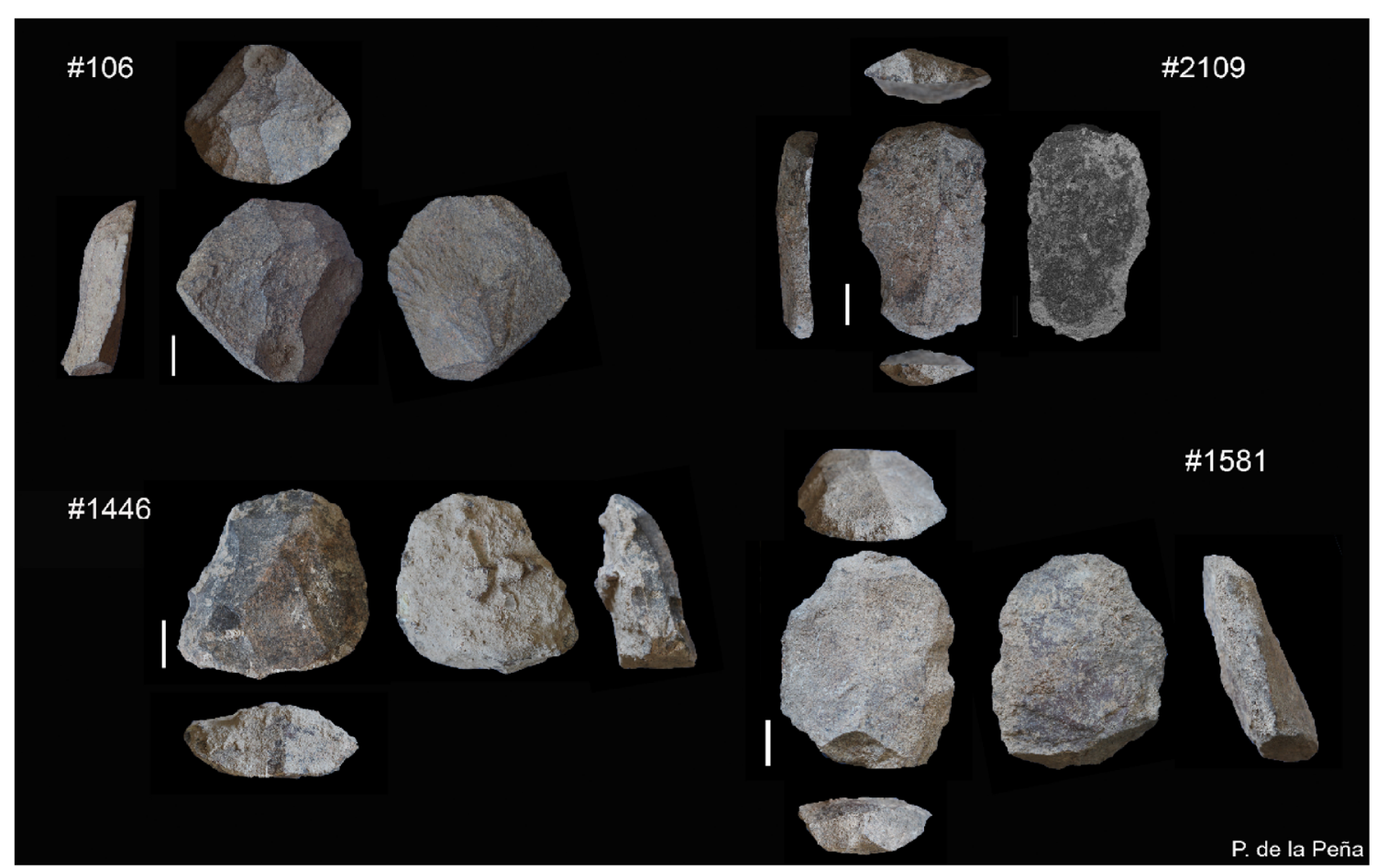

Fig. 10 MSA thick end-scrapers from the 2018 excavation at Olieboomspoort. Piece \#2109 is a doubled end-scraper. All scales are $1 \mathrm{~cm}$ and all pieces are orientated with the platform down and flat (pictures P. de la Peña)

MSA-LSA sequence (Barker and Mackey 1959; Mason 1957, 1959, 1962, 1982; Klein 1970, 1977, 1983, 2000; Mitchell 2002; van der Ryst 2007; Underhill 2011; Kuman 2016). This rests on Mason's discovery in 1954 of ESA artefacts from the lowermost deposits and on van der Ryst's recovery in 1997 of a sandstone handaxe and a cleaver at the base of her test-trench (van der Ryst 2007). Based on previous work at the site, when we reopened this test-trench in 2018, we expected to encounter bedrock at ca. $1.8 \mathrm{~m}$. Instead, underneath a basal layer rich in medium to large clasts, most likely interpreted as the bedrock in the past (Mason 1962; van der Ryst 2007), we uncovered more archaeological deposits containing MSA artefacts and, going deeper, we did not find any ESA tools. Preliminary ground-penetrating radar investigation conducted at the site in 2019 confirms that bedrock is at least $1 \mathrm{~m}$ lower than estimated during previous excavations. Future fieldwork will investigate the depth and nature of these lower deposits. The stratigraphic relationship between the ESA artefacts retrieved previously and these lower MSA deposits also requires further clarification.

\section{Lithic assemblage}

The 2018 excavation in squares B2 and B3 yielded a rich lithic assemblage with 2500 piece-plotted stone tools from units GS and YRS, which are combined here. This lithic assemblage includes 20 cores and 64 retouched pieces (Tables 2 and 3; Figs. 8, 9, 10 and 11). We analysed in detail 47 pieces offering relevant technological information. Nonetheless, for this preliminary assessment, we went through all of the blanks, including chips under $2 \mathrm{~cm}$ in size, to select the most informative pieces.

The first comment regarding the lithic assemblage is a taphonomic one and regards its general state of preservation. Numerous pieces exhibit clear evidence of rounding, which could indicate that this part of the sequence represents a secondary deposit. Most pieces are encrusted with calcium carbonate concretions, which, together with the alterations mentioned previously, hinders the identification of the different rock types knapped at the site. Concretions and taphonomic alterations also prevent the description of the main technological characteristics of the lithic assemblage. Detailed technological analysis of the complete assemblage is therefore currently difficult since for most pieces it is not possible to determine the main knapping stigmas. To obtain some preliminary understanding of the lithic assemblage (and while light acid preparation is ongoing to clean the assemblage), we selected from each décapage the pieces that offer some degree of technological information. These include pieces with a clearly visible dorsal pattern, platform preparation and knapping accidents such as overshoots or hinge flakes, as well as cores and retouched pieces. Cores are useful because they document the main reduction sequences and, following a chaîne opératoire approach, retouched pieces might underline the main objectives of the knapping process, in terms of blank 


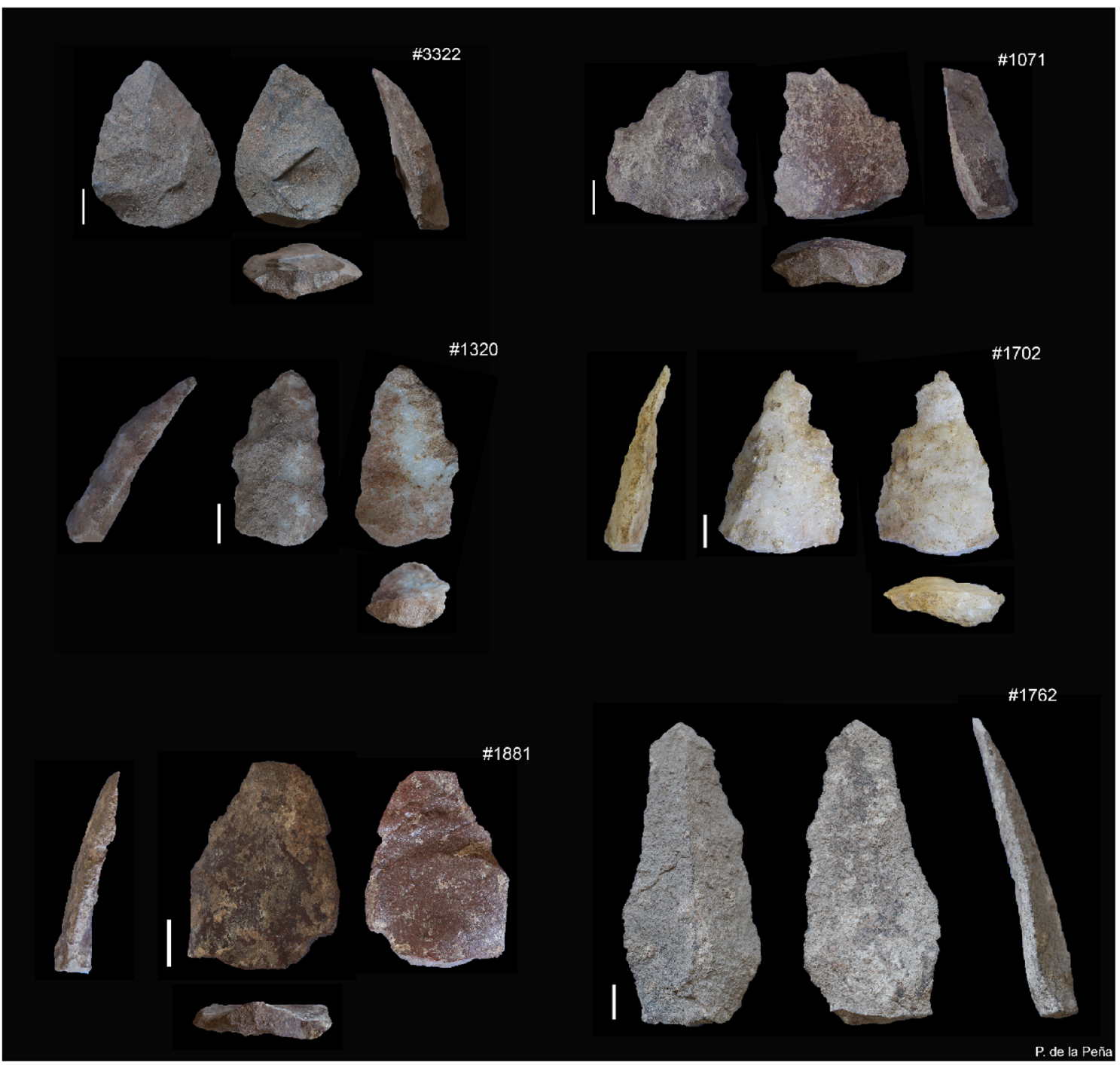

Fig. 11 Different MSA triangular blanks retouched and unretouched from the 2018 excavation at Olieboomspoort. Pieces \#3322, \#1702 and $\# 1881$ are Levallois points. Piece \#3322 has an invasive flat direct retouch on its dorsal face. Piece \#1071 has denticulate direct retouch on both

production. The methodology followed for this initial technological classification is described in de la Peña (2015) and, regarding the Levallois technology present in the assemblage, we follow the classic works of Bordes (Ed. 2000) and Boëda (1994).

The main raw materials knapped at the site are quartzite, quartz, hornfels, dolerite and probably other igneous rocks, which are difficult to determine without thin section analyses (ongoing analysis). The general technology throughout all décapages is clearly Levallois-like, with several éclats débordants, Levallois flakes, Levallois points, pseudoLevallois points and even clear Levallois cores (Tables 1 and 2; Figs. 8 to 11). Blades are common and related to a Levallois-like type of reduction. One of the specific challenges for future studies will be to see how blades and triangular blanks relate to each other in the reduction sequence. It will lateral edges. Piece \#1320 has direct simple retouch on both lateral edges. All scales are $1 \mathrm{~cm}$ and all pieces are oriented with the platform down and flat (pictures P. de la Peña)

be interesting to decipher whether they are the by-product of independent reduction sequences or whether they were knapped in the same type of reduction sequence with different phases for the production of triangular flakes and blades. Notably, one large blade blank (larger than $10 \mathrm{~cm}$ in breadth) was documented in one of the décapages. The technological characterisation of the production of these large blades should also be another main objective of the technological analysis of this collection. Nonetheless, the great breadth of these blanks might also point to a Levallois variant rather than a prismatic shaping of the cores.

The most abundant cores are Levallois cores, followed by bipolar cores in quartz (Table 2). All Levallois cores are recurrent centripetal (Boëda 1993, 1994) with the exception of one piece showing the last scar with a triangular shape (\#1862 in Fig. 8). Based on our preliminary 
observations, bipolar reduction is abundant in the LSA lithic assemblage recovered in the uppermost deposits excavated by M. van der Ryst and small bipolar cores identified in the MSA deposits could come from the overlying Holocene units. This is something that future technological analyses should tackle with a larger sample including the deepest LSA layers from the site (material from van der Ryst's excavation).

The most common categories of retouched pieces are retouched flakes, end-scrapers, Levallois and pseudoLevallois retouched pieces, as well as denticulates (Table 3; Figs. 9,10,11). Almost all of the retouched flakes and endscrapers are made on thick flakes.

A full techno-typological analysis of ESA artefacts retrieved from OBP by R. Mason in 1954 is ongoing and here we provide some preliminary descriptions of these artefacts (Fig. 12). This assemblage includes two complete large cutting tools (LCTs; Fig.12). LCTs are characteristic of the Acheulean stone tool industry (de la Torre 2016), and they confirm the technological roots of these artefacts within the ESA. Both LCTs are cleavers manufactured on quartzite. The assemblage also includes a large quartzite flake, a large modified flake produced on hornfels and a single quartzite discoidal core (Fig. 12). These three tools are weathered and rolled compared to the MSA artefacts but technologically speaking they could be related to any period from the Oldowan to the MSA. At this stage, we regard their attribution to the ESA with caution.

\section{Ochre assemblage}

The OBP LSA ochre assemblage from van der Ryst's excavation contains 9474 pieces, ochre-stained grindstones, ochrestained tools, beads and bone (van der Ryst 2007). The Mason MSA ochre assemblage consists of 304 pieces of ochre (156 of which were unattributed); grindstones are also present, some with possible (unconfirmed) ochre residues (Mason 1962; Watts 1998).

The ochre assemblage from the new field campaigns at OBP (units GS and YRS) includes 452 probable ochre pieces (excluding those $<10 \mathrm{~mm}$ ), weighing over $4.5 \mathrm{~kg}$. Many of the pieces have calcium carbonate concretions on them (Fig. 13) and we performed chemical preparation of pieces. Preliminary examination has shown, consistent with previous analyses, that the predominant raw materials are hard, heavy, sometimes magnetic, specularite and haematite varieties. Other, softer raw materials, such as shales and mudstones, are present in small quantities. The majority of ochre pieces in the assemblage have red or purple streaks, often in darker shades. Compared with other MSA ochre assemblages, there is a low percentage of utilised pieces, with use-traces found on 15 pieces (Fig. 13a-b), most of which have grinding wear traces. A further 41 pieces have signs of possible utilisation in the form of smoothing and polish. These finds are consistent with the analysis of the Mason ochre assemblage (Watts 1998, 2002). Interpretations of OBP as a primary processing site for locally procured specular haematite will be investigated further. Watts (1998) and van der Ryst (2007) noted

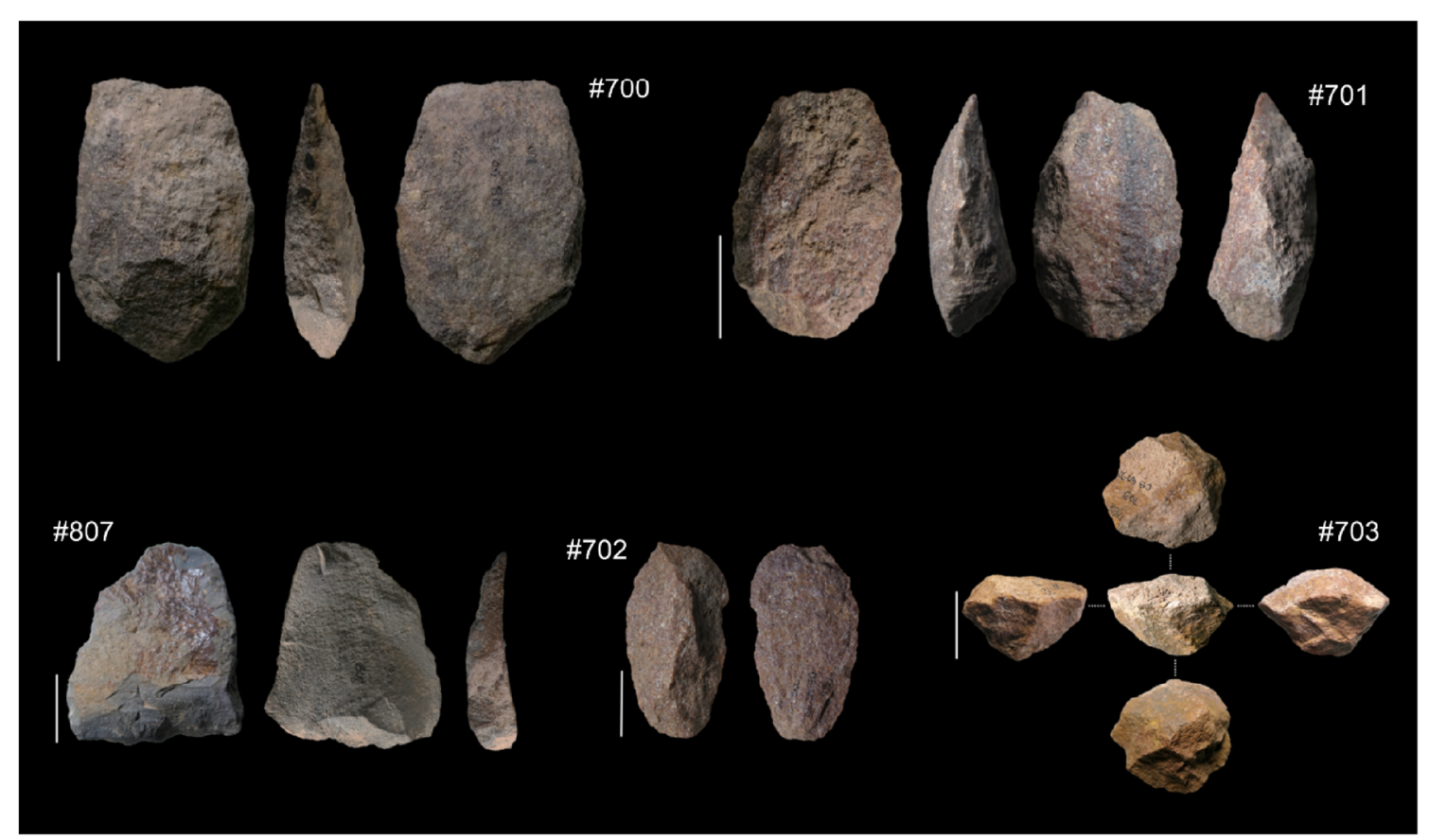

Fig. 12 ESA tools from Mason's excavations. Artefacts 700 and 701 are both coarse-grained quartzite cleavers. Artefact 702 is a complete quartzite flake. Artefact 807 is a large, modified flake on hornfels. Artefact 703 is a quartzite discoidal core. All scales are $5 \mathrm{~cm}$. Artefact views are rotated left to right in sequence (pictures K. Shadrach) 
Fig. 13 Selection of ochre pieces from OBP MSA layers (20182019 excavation): (a) utilised, faceted specularite \#656-1 (GS 6, B2c), (b) utilised specularite \#3462-2 (YRS 7, B2c), (c) Shaley specularite \#3302-1 (YRS 5, B2c) with possible smoothing, (d) unutilised specularite \#1384 (GS 4, B2b) and (e) specularite \#605-1 (GS 5, B2d) with utilised surface (pictures J. Culey). The scale is 1 $\mathrm{cm}$

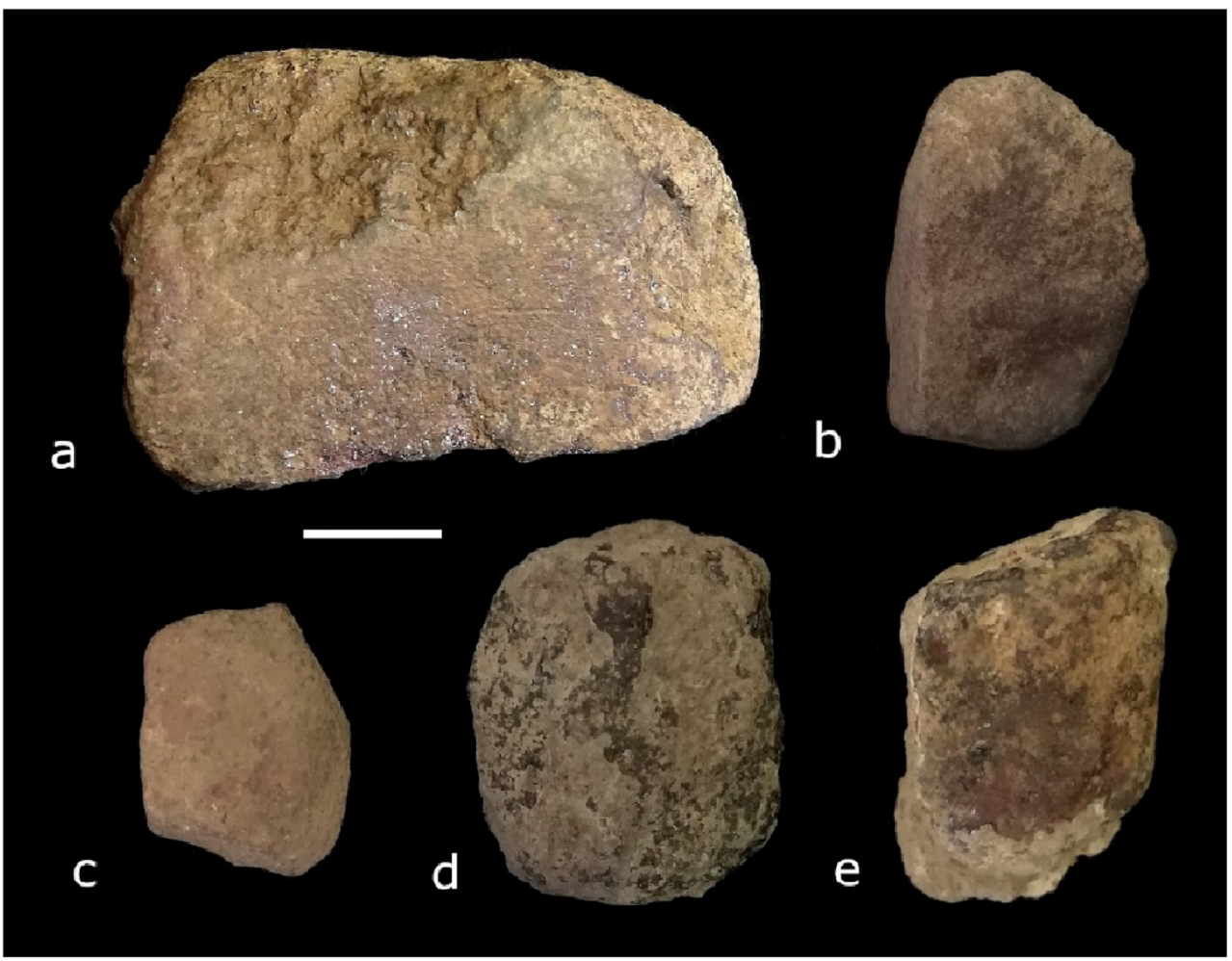

numerous sources near the shelter such as the Thabazimbi iron ore deposits of the Penge Formation, a red ochre quarry in the Soutpansberg and iron-rich deposits near Lephalale. We intend to undertake a raw material provenance study in the area to determine probable sources of the ochre, and establish ochre transportation distances. We plan to use portable Xray fluorescence ( $\mathrm{pXRF}$ ), scanning electron microscopy (SEM) and X-ray diffraction (XRD) analyses to determine ochre types and potential sources. Understanding the uses and processing of this unique ochre type will improve the understanding of ochre-related behaviours at inland MSA sites as well as regional ochre use strategies and potential regional networks during the MSA.

\section{Faunal remains}

Our 2018 excavation campaign yielded abundant and relatively well-preserved fossilised faunal remains $(n$ plotted $=774$ bones and 43 dental remains) - a significant discovery since faunal remains from the MSA layers at OBP have not been described previously. The preservation of dental remains facilitates taxonomical attributions. Identifiable remains were selected to obtain an initial taxonomic list (Table 4), which provides insights into palaeohabitats present around the site. A taphonomic analysis of the faunal remains is ongoing. Many of these remains are encrusted and need to go through a phase of light acid preparation before inspection of bone surface
Table 4 Taxonomic attributions of the identifiable faunal remains retrieved during the 2018 excavation at Olieboomspoort

\begin{tabular}{|c|c|c|c|}
\hline Class/order & Species & Common name & NISP \\
\hline \multirow[t]{9}{*}{ Artiodactyla } & Raphicerus campestris & Steenbok & 2 \\
\hline & Raphicerus sp. & Steenbok/grysbok & 1 \\
\hline & Redunca arundinum & Southern reedbuck & 2 \\
\hline & Redunca sp. & Reedbuck & 4 \\
\hline & Oreotragus oreotragus & Klipspringer & 2 \\
\hline & Alcelaphus sp. & Hartebeest & 3 \\
\hline & Connochaetes sp. & Wildebeest & 2 \\
\hline & Hippotragus sp. & Roan/sable antelope & 2 \\
\hline & Tragelaphus oryx & Eland & 1 \\
\hline \multirow[t]{2}{*}{ Perissodactyla } & Equus cf. capensis & Extinct giant cape zebra & 7 \\
\hline & Equus sp. & Zebra & 5 \\
\hline Primates & Papio sp. & Baboon & 1 \\
\hline \multirow[t]{2}{*}{ Lagomorpha } & Lepus sp. & Hare & 3 \\
\hline & Pronolagus sp. & Rabbit & 1 \\
\hline \multirow[t]{2}{*}{ Carnivora } & Proteles cristata & Aardwolf & 1 \\
\hline & Felis lybica & African wild cat & 1 \\
\hline \multirow[t]{3}{*}{ Reptiles } & Stigmochelys pardalis & Leopard tortoise & 8 \\
\hline & Kinixys sp. & Hinge-back tortoise & 1 \\
\hline & Serpentes indet. & Large snake & \\
\hline \multirow[t]{2}{*}{ Gastropoda } & Achatina sp. & Giant land snail & 1 \\
\hline & & Total & 48 \\
\hline
\end{tabular}


modifications (e.g. identification of butchery marks) can be conducted.

The taxonomic composition of the faunal spectrum underlines three main palaeoecological signals: the predominance of open grasslands, the proximity of the Riet Spruit and the location of the site within a rocky area. Several ungulate taxa are typically associated with open habitats such as open grasslands, plains or woodland savanna and include the blue wildebeest, eland, zebra, hartebeest, roan/sable antelope and steenbok (Skinner and Chimimba 2005). Some of these species, namely plains zebras, elands and roan antelopes, tend to occur today in association in southern African open plains. The presence of the aardwolf confirms this signal since this hyaenid feeds almost entirely on termites from the genus Trinervitermes, which inhabit open grasslands (e.g. Cooper and Skinner 1979; Richardson 1987; Skinner and Chimimba 2005). The proximity of the site to the Riet Spruit is illustrated by the occurrence of the southern reedbuck, a species with a high-water supply requirement (Skinner and Chimimba 2005). The proximity to water is an ecological requirement also shared by plains zebras. Baboons, klipspringers and leporids, still abundant in the vicinity of the site today, thrive in cliffs and rocky areas.

Of particular note is the recovery of nine equid teeth, found in close proximity to one another and that most likely belong to a single individual (Fig. 14). These are awaiting full morphological descriptions but, due to their large dimensions, we attribute them tentatively to the extinct giant Cape horse, Equus cf. capensis. E. capensis is one of several large ungulate taxa in southern Africa that were affected by the late Quaternary megafaunal extinction (Faith 2014 and references therein). While its possible presence at OBP confirms the Pleistocene age of the deposits, it is not possible to provide further biochronological constraints. In southern Africa, the earliest E. capensis specimens come from late Pliocene deposits at Langebaanweg (Hooijer 1976) and the remains of this species are documented at many Middle to Late Pleistocene sites across the region (Churcher 2006 and references therein; Faith 2014 and references therein). E. capensis remains are for instance documented at Bushman Rock Shelter in layers recently correlated to MIS5 (Badenhorst and Plug 2012; Porraz et al. 2018), Border Cave in layer 2BS dated to ca. $48 \mathrm{ka}$ and attributed to MSA 3 (Klein 1977; Grün and Beaumont 2001), and from the ESA (1-3) and MSA (4-8) beds at Cave of Hearths (Haradon 2010). This large equid species, with a body weight estimated to at least $400 \mathrm{~kg}$ and a height at the withers of ca. $150 \mathrm{~cm}$ (Eisenmann 2000), seems to go extinct at the onset of the Holocene at ca. $11 \mathrm{ka}$ BP in southern Africa (Faith 2014). Analyses of stable carbon $\left(\delta^{13} \mathrm{C}\right)$ and oxygen $\left(\delta^{18} \mathrm{O}\right)$ isotope ratios indicate that E. capensis was a grazer (Lee-Thorp and Beaumont 1995; Codron et al. 2008), like the other large ungulates identified from the OBP MSA fauna.

\section{Age of the MSA fossil assemblage}

\section{Material}

The recovery of ungulate teeth during the 2018 excavation offers the possibility to date directly the faunal assemblage and to provide an age constraint for the associated MSA lithics. We collected two Equus sp. molars (lab IDs: \#536 and \#537) from the GS/unit 1 deposits in sub-square B2c (Fig. 6), together with the associated sediment for combined U-series and ESR dating. The first tooth was found in décapage 11 of the unit GS and the second tooth was found $4 \mathrm{~cm}$ deeper, in décapage 13 of the same unit. Horizontally speaking, both teeth were found $20 \mathrm{~cm}$ from one another within square B2c.

\section{Methods: combined U-series-ESR dating}

\section{Sample preparation}

We prepared the fossil teeth following a standard ESR dating procedure, as in Duval et al. (2019). The enamel layer was mechanically separated from the other dental tissues and both inner and outer surfaces were removed with a dentist drill to eliminate the volume that received an external alpha dose. Initial and removed enamel thicknesses were measured using a digital calliper. The clean enamel and dentine samples were ground and sieved $<200 \mu \mathrm{m}$ to obtain homogeneous powders for ESR and U-series analyses.

\section{ESR dose evaluation}

We performed the ESR dose evaluation at the Centro Nacional de Investigación sobre la Evolución Humana (CENIEH), Spain. Dose evaluation utilised the multiple aliquot additive dose (MAAD) method. The enamel powder was split into eleven aliquots and irradiated with a Gammacell $1000 \mathrm{Cs}-137$ gamma source (dose rate $=6.27 \pm 0.14 \mathrm{~Gy} /$ $\mathrm{min}$ ) to the following doses: 0, 49.0, 98.0, 147.0, 245.0, $342.9,489.9,685.9,881.9,1469.8$ and 3429.5 Gy.

We carried out ESR measurements at room temperature with an EMXmicro 6/1 Bruker ESR spectrometer coupled to a standard rectangular ER 4102ST cavity. We used the following procedure to minimise the analytical uncertainties on the measurements: (i) all aliquots of a given sample were carefully weighed into their corresponding tubes and a variation of $<1 \mathrm{mg}$ was tolerated between aliquots; (ii) ESR measurements were performed using a Teflon sample tube holder inserted from the bottom of the cavity to ensure that the vertical position of the tubes remained exactly the same for all aliquots. We used the following acquisition parameters: 1-15 scans depending on the aliquots and samples considered, 1$\mathrm{mW}$ microwave power, 1024 points resolution, 15-mT sweep 

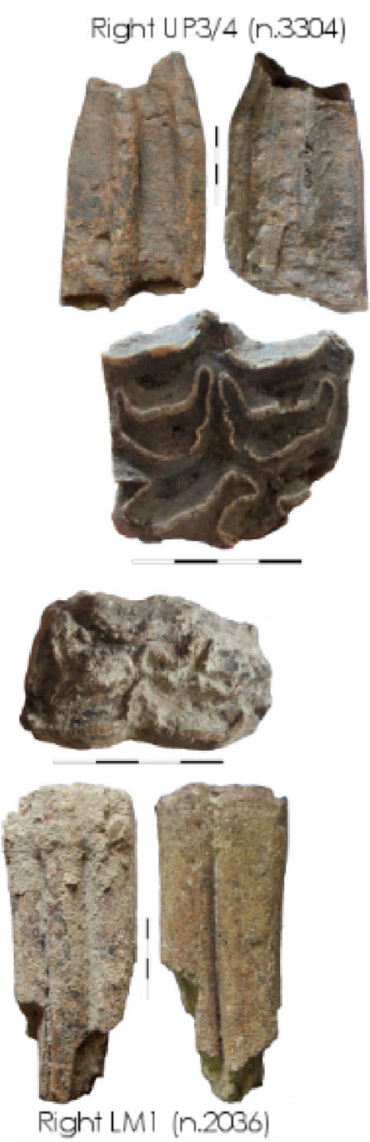
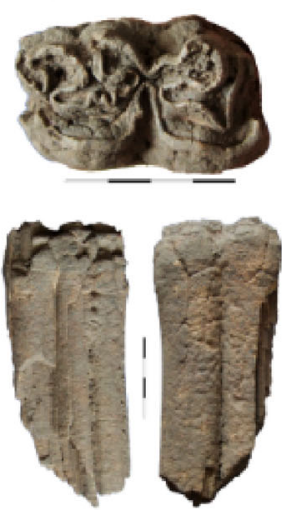

Right LP4 (n.745)
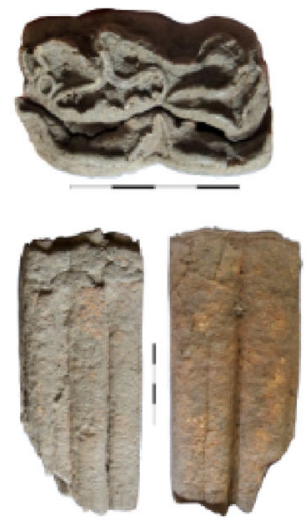

Rignt LP3 (n.744)
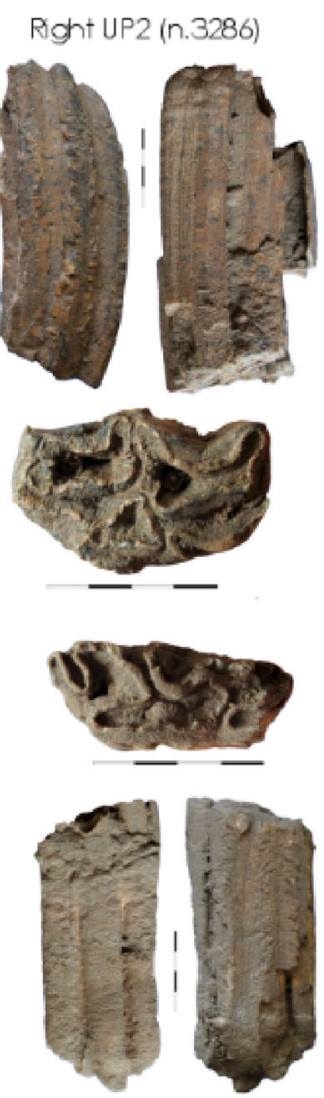

Right LP2 (n.743)

Fig. 14 Six of the best-preserved nine equid teeth attributed to Equus cf. capensis, possibly the extinct Giant Cape Horse, recovered from the MSA layers of Olieboomspoort excavated in 2018. All scales are $2 \mathrm{~cm}$ (pictures A. Val)

width, 100-kHz modulation frequency, 0.1-mT modulation amplitude, 20-ms conversion time and 5-ms time constant. All aliquots were measured within a short time interval $(<1$ h). We repeated this procedure twice over successive days without removing the enamel from the ESR tubes between measurements in order to evaluate intensity and equivalent dose $\left(D_{\mathrm{E}}\right)$ precisions.

We extracted the ESR intensities from T1-B2 peak-to-peak amplitudes of the ESR signal (Grün 2000a) after a cubic baseline correction, and then normalised to the corresponding number of scans and aliquot mass. $D_{\mathrm{E}}$ values were obtained by fitting a single saturating exponential (SSE) through the mean ESR intensities derived from the repeated measurements. Fitting was performed with Microcal OriginPro 9.1 software, which is based on a Levenberg-Marquardt algorithm by chi-square minimisation. Data were weighted by the inverse of the squared ESR intensity $\left(1 / I^{2}\right)$ (Grün and Brumby 1994). The ESR dose response curves (DRC) are displayed in Fig. 15, while the detailed fitting results are provided in Table 5.

Solution U-series analyses by MC-ICPMS Solution U-series analyses of powdered enamel and dentine were carried out using a Nu Plasma HR MC-ICP-MS in the Radiogenic
Isotope Facility (RIF) at the School of Earth and Environmental Sciences, University of Queensland (Australia), following chemical treatment procedures and MC-ICP-MS analytical protocols described elsewhere (e.g. Zhao et al. 2001; Clark et al. 2014). Powdered sub-samples weighing $1-5 \mathrm{mg}$ were spiked with a mixed ${ }^{229} \mathrm{Th}^{233} \mathrm{U}$ tracer and then completely dissolved in concentrated $\mathrm{HNO}_{3}$. After digestion, each sample was treated with $\mathrm{H}_{2} \mathrm{O}_{2}$ to decompose trace amounts of organic matters and to facilitate complete sample-tracer homogenisation. $\mathrm{U}$ and $\mathrm{Th}$ were separated using conventional anion-exchange column chemistry using BioRad AG 1-X8 resin. After stripping off the matrix from the column using double-distilled $7 \mathrm{~N} \mathrm{HNO}_{3}$ as eluent, $3 \mathrm{ml}$ of a $2 \% \mathrm{HNO}_{3}$ solution mixed with trace amount of $\mathrm{HF}$ was used to elute both $\mathrm{U}$ and $\mathrm{Th}$ into a $3.5-\mathrm{ml}$ pre-cleaned test tube. After column chemistry, the U-Th mixed solution was injected into the MC-ICP-MS through a DSN-100 desolvation nebuliser system with an uptake rate of around $0.07 \mathrm{ml}$ per minute. U-Th isotopic ratio measurement was performed on the MC-ICP-MS using a detector configuration to allow simultaneous measurements of both $U$ and Th. Closed-system U-series ages were calculated using the Isoplot/Ex 3.75 Program (Ludwig 2012) and decay constants from Cheng et al. (2000). Analytical results are given in Table 6. 
Table 5 ESR fitting results obtained for the various enamel samples. Intensity precision is expressed as the mean coefficient of variation of the ESR intensities obtained for all the aliquots of a given sample over the three repeated measurements. $D_{\mathrm{E}}$ precision is the variation of the $D_{\mathrm{E}}$ values derived from each repeated measurement of a given sample. All errors are given at 1- $\sigma$ confidence level

\begin{tabular}{lll}
\hline Sample & $\# 536$ & $\# 537$ \\
\hline Average weight per aliquot (mg) & $19.7 \pm 0.4$ & $19.5 \pm 0.5$ \\
Number of repeated measurements & 2 & 2 \\
Measurement precision $(\%)$ & 1.7 & 0.3 \\
Fitting \#1 (data weighting by $\left.1 / I^{2}\right)$ & & \\
$D_{\mathrm{E}}$ precision $(\%)$ & 0.1 & 3.1 \\
Adj. $r$-square & 0.997 & 0.992 \\
$D_{\mathrm{E} 1}(\mathrm{~Gy})$ & $167 \pm 5.15(3.1 \%)$ & $160.7 \pm 8.39(5.2 \%)$ \\
$D_{\max }(\mathrm{Gy})$ & 3430 & 3430 \\
$D_{\max } / D_{\mathrm{E} 1}$ & 20.6 & 21.3 \\
Fitting $\# 2$ (data weighting by $\left.1 / I^{2}\right)$ & & \\
Adj. $r$-square & 0.997 & 0.990 \\
$D_{\mathrm{E} 2}(\mathrm{~Gy})$ & $171 \pm 7.37(4.3 \%)$ & $159 \pm 12.0(7.6 \%)$ \\
$D_{\max }(\mathrm{Gy})$ & 1470 & 1470 \\
$D_{\max } / \mathrm{D}_{\mathrm{E} 1}$ & 8.6 & 9.3 \\
$D_{\mathrm{E} 2} / D_{\mathrm{E} 1}$ ratio & 1.03 & 0.99 \\
\hline
\end{tabular}

U-series/ESR age calculations $\mathrm{U}$, Th and $\mathrm{K}$ contents were obtained from the ICP-OES/MS analysis of the dry raw sediment (previously powdered and homogenised) following a four-acid digest preparation procedure. We used the following parameters for the dose rate calculations: an alpha efficiency of $0.13 \pm 0.02$ (Grün and Katzenberger-Apel 1994), MonteCarlo beta attenuation factors from Marsh (1999), dose-rate conversion factors from Guérin et al. (2011), an estimated water content of 0 and $5 \pm 3 \mathrm{wt} \%$ in enamel and dentine, respectively. A sample geometry sediment/enamel/dentine and cement/enamel/dentine was used for the beta dose rate attenuations of samples \#536 and \#537, respectively.

We performed age calculations with USESR, a Matlabbased programme (Shao et al. 2014) using the US and AU models defined by Grün et al. (1988) and Shao et al. (2012), respectively. We also carried out additional CSUS-ESR age

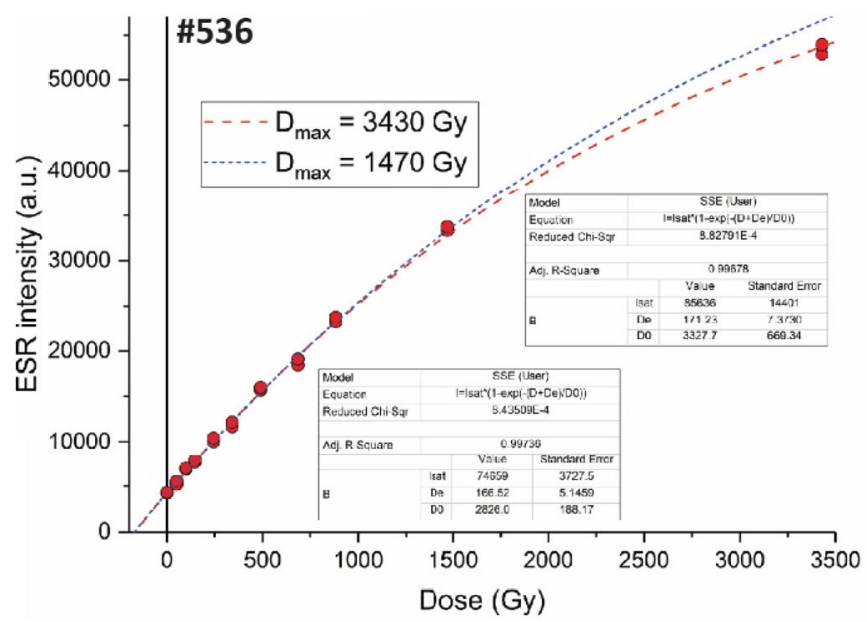

calculations using DATA, a DOS-based programme (Grün 2009). The CSUS-ESR model defined by Grün (2000b) is based on the assumption that all of the uranium migrated into the sample at a time given by the closed system U-series age. The CSUS-ESR age is the maximum age that can be derived from a given U-series and ESR data set. Age calculations using the US or AU and CSUS models encompass all possible uptake scenarios. Table 7 presents data inputs and outputs.

\section{Results and discussion}

\section{ESR data}

The two enamel samples were measured using a similar amount of material (about $20 \mathrm{mg}$ per aliquot) (Table 5). Intensity precision was good $(<2 \%)$, resulting in highly

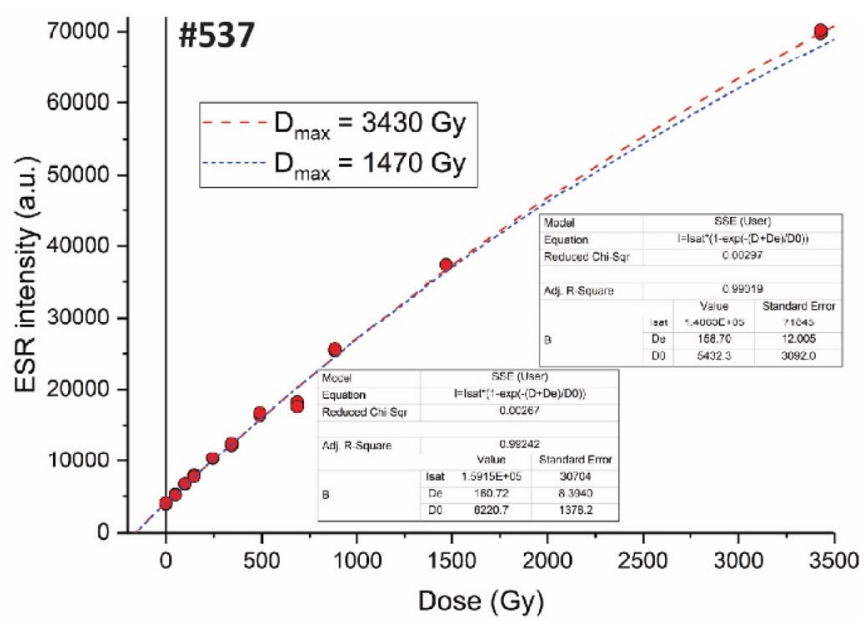

Fig. 15 ESR dose response curves obtained for the two samples. Fittings were performed over the full dose range $\left(D_{\max }=3430 \mathrm{~Gy}\right)$ and for a selected $D_{\max }$ of 1470 Gy in order to meet the recommendations by Duval and Grün (2016) 
Table 6 U-series dating results obtained from solution MC-ICPMS analyses performed at University of Queensland. All errors are 2- $\sigma$. Ratios in parentheses are activity ratios. Bulk-Earth ${ }^{230} \mathrm{Th} /{ }^{232} \mathrm{Th}$ value of $4.4 \times 10^{-6}$ with arbitrarily assigned $50 \%$ uncertainty was used for detrital ${ }^{230} \mathrm{Th}$ correction to calculate the corrected ${ }^{230} \mathrm{Th}$ ages. Uncorr. and corr. denote uncorrected and corrected, respectively.

\begin{tabular}{|c|c|c|c|c|c|c|c|c|}
\hline Sample ID & Tissue & $\mathrm{U}(\mathrm{ppm})$ & ${ }^{232} \mathrm{Th}$ (ppb) & $\left({ }^{230} \mathrm{Th} /{ }^{232} \mathrm{Th}\right)$ & $\left({ }^{230} \mathrm{Th} /{ }^{238} \mathrm{U}\right)$ & $\left({ }^{234} U /{ }^{238} U\right)$ & Uncorr. ${ }^{230} \mathrm{Th}$ age (ka) & Corr. ${ }^{230}$ Th age (ka) \\
\hline \multirow[t]{2}{*}{ \#536 } & Enamel & $0.0979 \pm 0.0003$ & $22.95 \pm 0.037$ & $10.88 \pm 0.11$ & $0.840 \pm 0.009$ & $1.539 \pm 0.003$ & $81.4 \pm 1.2$ & $77.1 \pm 2.0$ \\
\hline & Dentine & $8.420 \pm 0.051$ & $270.4 \pm 1$ & $6.75 \pm 0.033$ & $0.0715 \pm 0.0005$ & $1.448 \pm 0.007$ & $5.506 \pm 0.047$ & $4.85 \pm 0.33$ \\
\hline \multirow[t]{3}{*}{ \#537 } & Enamel & $0.1655 \pm 0.0004$ & $6.560 \pm 0.013$ & $62.22 \pm 0.49$ & $0.813 \pm 0.006$ & $1.521 \pm 0.003$ & $79.06 \pm 0.90$ & $78.34 \pm 0.94$ \\
\hline & Dentine & $3.498 \pm 0.001$ & $95.67 \pm 0.15$ & $65.26 \pm 0.19$ & $0.588 \pm 0.002$ & $1.493 \pm 0.003$ & $53.00 \pm 0.24$ & $52.48 \pm 0.31$ \\
\hline & Cement & $5.370 \pm 0.003$ & $181.60 \pm 0.17$ & $61.53 \pm 0.11$ & $0.686 \pm 0.001$ & $1.523 \pm 0.002$ & $62.75 \pm 0.16$ & $62.13 \pm 0.28$ \\
\hline
\end{tabular}

Table 7 Data inputs and outputs corresponding to the combined US-ESR age calculations. All errors are given at a $1-\sigma$ confidence level, including the U-series data (1) taken from Table 6 . Final $D_{\mathrm{E}}$ errors are made of a combination of errors from the fitting (Table 5) and the dose rate from the gamma source $(2.3 \%)$. Post-Rn equilibrium was considered in dental tissues and sediment. n.a. not applicable

\begin{tabular}{|c|c|c|}
\hline Sample & \#536 & \#537 \\
\hline \multicolumn{3}{|l|}{ Enamel } \\
\hline Dose (Gy) & $171.2 \pm 8.4$ & $158.7 \pm 12.5$ \\
\hline $\mathrm{U}(\mathrm{ppm})^{(1)}$ & $0.098 \pm 0.000$ & $0.166 \pm 0.000$ \\
\hline${ }^{234} U{ }^{238} U^{(1)}$ & $1.539 \pm 0.002$ & $1.521 \pm 0.001$ \\
\hline${ }^{230} \mathrm{Th} /{ }^{234} \mathrm{U}^{(1)}$ & $0.546 \pm 0.003$ & $0.534 \pm 0.002$ \\
\hline Alpha Efficiency & $0.13 \pm 0.02$ & $0.13 \pm 0.02$ \\
\hline Water content $(\%)$ & 0 & 0 \\
\hline Initial enamel thickness $(\mu \mathrm{m})$ & $1143 \pm 114$ & $1436 \pm 144$ \\
\hline \multicolumn{3}{|l|}{ Dentine } \\
\hline $\mathrm{U}(\mathrm{ppm})^{(1)}$ & $8.420 \pm 0.026$ & $3.498 \pm 0.002$ \\
\hline${ }^{234} U{ }^{238} U^{(1)}$ & $1.448 \pm 0.003$ & $1.493 \pm 0.002$ \\
\hline${ }^{230} \mathrm{Th} /{ }^{234} \mathrm{U}^{(1)}$ & $0.049 \pm 0.000$ & $0.394 \pm 0.001$ \\
\hline Water $(\%)$ & $5 \pm 3$ & $5 \pm 3$ \\
\hline Removed enamel thickness $(\mu \mathrm{m})$ & $152 \pm 15$ & $49 \pm 5$ \\
\hline \multicolumn{3}{|l|}{ Cement } \\
\hline $\mathrm{U}(\mathrm{ppm})^{(1)}$ & n.a. & $5.370 \pm 0.001$ \\
\hline $\operatorname{Th}(\mathrm{ppm})^{(1)}$ & n.a. & $1.523 \pm 0.001$ \\
\hline $\mathrm{K}(\%)^{(1)}$ & n.a. & $0.450 \pm 0.000$ \\
\hline Water $(\%)$ & n.a. & $5 \pm 3$ \\
\hline Removed thickness $(\mu \mathrm{m})$ & n.a. & $133 \pm 13$ \\
\hline \multicolumn{3}{|l|}{ Sediment } \\
\hline $\mathrm{U}(\mathrm{ppm})$ & $3.47 \pm 0.14$ & $2.83 \pm 0.12$ \\
\hline Th (ppm) & $11.34 \pm 0.48$ & $12.04 \pm 0.51$ \\
\hline $\mathrm{K}(\%)$ & $0.34 \pm 0.01$ & $0.36 \pm 0.01$ \\
\hline Water $(\%)$ & $15 \pm 5$ & $15 \pm 5$ \\
\hline Removed thickness $(\mu \mathrm{m})$ & $158 \pm 16$ & n.a. \\
\hline \multicolumn{3}{|l|}{ Combined U-series/ESR age calculations } \\
\hline Internal dose rate $\left(\mu \mathrm{Gy} \mathrm{a}{ }^{-1}\right)$ & $19 \pm 4$ & $32 \pm 6$ \\
\hline Beta dose rate, dentine $\left(\mu \mathrm{Gy} \mathrm{a}^{-1}\right)$ & $9 \pm 2$ & $12 \pm 2$ \\
\hline Beta dose rate, sediment or cement $\left(\mu \mathrm{Gy} \mathrm{a}^{-1}\right)$ & $88 \pm 7$ & $18 \pm$ \\
\hline Gamma + cosmic dose rate $\left(\mu \mathrm{Gy} \mathrm{a}^{-1}\right)$ & $1032 \pm 44$ & $1004 \pm 44$ \\
\hline Total dose rate $\left(\mu \mathrm{Gy} \mathrm{a}^{-1}\right)$ & $1141 \pm 107$ & $1065 \pm 136$ \\
\hline$p$ or $n$ enamel & -0.4 & -0.3 \\
\hline$p$ or $n$ dentine & 24.7 & 0.5 \\
\hline$P$ cement & n.a. & 0.1 \\
\hline US-ESR age (ka) & $150 \pm 12$ & $149 \pm 15$ \\
\hline
\end{tabular}


repeatable $D_{\mathrm{E}}$ estimates ( $D_{\mathrm{E}}$ variation between 0.1 and $3.1 \%$ ). Fitting was performed using a maximum irradiation dose $\left(D_{\max }\right)$ of $1470 \mathrm{~Gy}$ in order to meet the recommendations of Duval and Grün (2016), who had previously shown that the $D_{\max } / D_{\mathrm{E}}$ ratio should be somewhere between 5 and 10 for $D_{\mathrm{E}}$ values $>100 \mathrm{~Gy}$. This results in $D_{\mathrm{E}}$ estimates that slightly differ by only $1-3 \%$ with the values initially derived from the DRC fitting with $D_{\max }=3430$ Gy (Table 5), demonstrating that the two sets of fitting results remain within 1- $\sigma$ error. Final $D_{\mathrm{E}}$ values are $171 \pm 7$ Gy and $159 \pm 12$ Gy for teeth $\# 536$ and \#537, respectively (Fig. 15).

\section{U-series results}

Solution U-series analyses returned very low uranium concentrations in the enamel samples $(<0.2 \mathrm{ppm}$; Table 6$)$, while they vary between $\sim 3.5$ and $\sim 8.4 \mathrm{ppm}$ in the dentine and cement. Additionally, there was no evidence of apparent uranium leaching, as all samples returned finite $\mathrm{U}$-series ages. These observations suggest that the samples are suitable for ESR dating.

Apparent U-series ages measured in the dental tissues vary between $\sim 52$ and $\sim 78 \mathrm{ka}$, except for the dentine of \#536, which returns a significantly younger age of $\sim 4.8 \mathrm{ka}$. In this case, the measured ${ }^{234} \mathrm{U} /{ }^{238} \mathrm{U}$ activity ratio of 1.448 is the lowest of the data set (Table 6). It corresponds to an initial ${ }^{234} \mathrm{U}{ }^{238} \mathrm{U}$ of 1.458 , whereas it ranges from 1.576 to 1.716 for the other samples: these differences suggest that the younger age result obtained for the dentine of \#536 may result from a more recent overprint associated with a different uranium uptake event compared to the other samples. This may have partially impacted the dentine and cement of \#537, which also return slightly younger ages. In comparison, the two enamel samples return highly consistent apparent ages of 77-78 ka, which may be interpreted as the most reliable chronological constraints: these ages should be regarded as minimum age estimates for the fossils, as uranium uptake may sometimes be significantly delayed after the death and burial of the teeth.

\section{Dose rate considerations}

Radioelement concentrations in the sediment vary within relatively narrow range (Table 7): $2.8-3.47 \mathrm{ppm}$ of $\mathrm{U}, 11.34$ $12.04 \mathrm{ppm}$ of Th and $0.34-0.36 \%$ of $\mathrm{K}$. They result in very close gamma dose rate values of 818-846 $\mu \mathrm{Gy} / \mathrm{a}$ for the two teeth, showing the relative homogeneity of the sediment in the vicinity of the samples.

\section{Combined U-series and ESR dating}

Because combined U-series and ESR age calculations did not show any evidence of uranium leaching, we could employ the US model for all dental tissues without any restrictions, while the use of the AU model was not required. These calculations return highly consistent US-ESR estimates of $150 \pm 12 \mathrm{ka}$ and $149 \pm 15 \mathrm{ka}$ for samples \#536 and \#537, respectively (Table 7). A mean age of $150 \pm 14 \mathrm{ka}(1 \sigma)$, corresponding to the arithmetic averages of the individual ages and errors, may be calculated from these two teeth. These results show that the dental tissues carry little weight in the total dose rate $(<6 \%)$, unlike the sedimentary environment, which accounts for between 77 and $82 \%$ depending on the tooth considered.

Consequently, the uncertainty around the uranium uptake modelling has a very limited (and almost negligible) impact on the calculated ages: the CSUS-ESR estimates are only 2 $3 \%$ older than the US-ESR results. Instead, we identified a few sources of uncertainty around the evaluation of the sedimentary dose that may have a more significant impact on the age results. For example, we performed age sensitivity tests by varying the long-term water content from 5 to $25 \%$ : these resulted in an increase of about 32-33 ka, from 134-135 ka (5\% water content) to 166-168 ka (25\%) (Fig. 16). In any case, regardless of the water content value considered, the US-ESR age estimates systematically indicate an MIS 6 chronology (191-130 ka; Lisiecki and Raymo 2005) for the two teeth. While current water content in the sediment has been measured to $<2 \%$ as part of the parallel ongoing luminescence dating study performed on a couple of samples collected from the test-trench, i.e. $\sim 3.5 \mathrm{~m}$ away from the B2 square, we consider in first instance that this value is unlikely to be an accurate estimate of the long-term water content. The proximity of the dripline and wall of the rock shelter as well as of the river ( $\sim \mathrm{m}$ away; Figs. 3 and 6) may have contributed to the circulation of percolating water through the sediment as well as more overall humid conditions in the past. Consequently, we consider the assumed value of $15 \pm 5 \%$ as a more reasonable estimate of past humidity conditions. Moreover, the large absolute error of $5 \%$ at $1-\sigma$ confidence level accounts for any fluctuation of humidity over time within the range of 5 to $25 \%$ at a $2-\sigma$ confidence level. The calculated US-ESR age estimates and associate error already encompass some variability in the long-term water content.

We performed cosmic dose rate evaluation using depth as the main source of uncertainty. However, one cannot

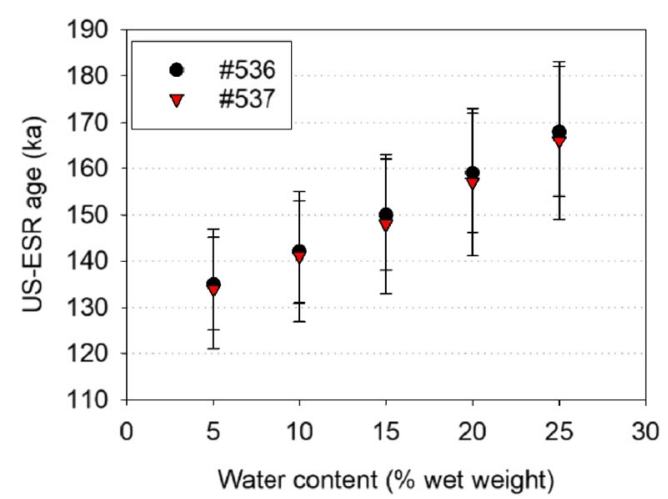

Fig. 16 Sensitivity tests evaluating the impact of the water content on the calculated US-ESR age results 
reasonably exclude that the proximity of the wall and the presence of a partial sandstone cover several metres above the excavation area may have played a role in attenuating some of the cosmic dose rate, assuming a rough attenuation of the cosmic dose rate by $50 \%$ following Richard et al. (2017) would produce an age increase of about $9 \%$, up to around 163 ka. This extreme scenario illustrates the relatively limited impact of this parametre on the calculated age, which would still be consistent with an MIS 6 chronology.

Finally, we acknowledge that one of the major sources of uncertainty in the dose rate evaluation results from the heterogeneity of the sedimentary environment around the teeth, with the presence of blocks and clasts in a silty to sandy sedimentary matrix. The majority of the clasts result from in situ breakdown and decaying of the walls and roof of the rock shelter (sandstones). Although the raw sediment samples analysed by ICP were previously powdered and homogenised, it is unlikely that the gamma dose rate derived from these analyses fully captured the true gamma dose rate with the exact proportion of clasts and sediment. Instead, we suspect the clasts were probably underrepresented in the laboratory analyses. A quick age simulation assuming a decrease or increase of the gamma dose rate by $15 \%$ would make the US-ESR estimates older by $\sim 13 \%$ and younger by $\sim 10 \%$ respectively. They would reach $169 \mathrm{ka}$ and $135 \mathrm{ka}$, but would still remain consistent with an MIS 6 chronology. Although this gives a rough idea of how this uncertainty may impact the age results, at this stage, any further interpretation of the current data would be speculation in the absence of in situ radioactivity measurement.

In summary, the two samples yield highly consistent combined US-ESR age estimates of about $150 \mathrm{ka}$. However, we do acknowledge the existence of a series of sources of uncertainty that may have a non-negligible impact on the age results, as illustrated by the various sensitivity tests performed. In any case, all scenarios consistently point towards an MIS6 age (130-191 ka) for the samples, which is at present the most reasonable and cautious conclusion. These results provide an indirect chronological constraint for the MSA lithic and ochre assemblages found in association with the fossil bones. New analyses in the future, and in particular in situ evaluations of the gamma dose rate, should help to refine the chronology of the site. Additionally, the samples collected a few metres away from the southern wall for luminescence dating purpose will not only give some key insights about the contemporaneity of the deposits with the fossil assemblage, but also help to chronostratigraphically correlate the units identified from the testtrench with the deposits excavated in the B2 and B3 squares.

\section{Pollen and phytolith preservation}

The slides contained few identifiable pollen ( $<20$ specimens), next to fungal remains and isolated algal cysts (Pseudoschizoaea, Table 8). We assume that oxidation processes, known to destroy the pollen exine, might be responsible for the low amount of pollen grains recovered (e.g. Mackenzie et al. 2015). This assumption is supported by the regular appearance of heavily corroded and/or crumpled pollen (termed Varia, see Table 8), with the exception of the sample from a depth of $40 \mathrm{~cm}$. Due to the low number of pollen grains per sample, a quantitative analysis was not possible and further processing of sediments for pollen analysis was not undertaken. The sample taken from $100-\mathrm{cm}$ depth (MSA deposits) was barren. The pollen spectra reflect typical savanna and woodland vegetation in the Summer Rainfall Zone with pollen of Combretaceae, Olea sp., Dombeya sp., Spirostachys africana, Peltophorum africanum, Burkea africana, Euclea sp. and pollen of herbs and shrublets like Poaceae, Asteraceae and Commelinaceae (Tables 8, 9, 10). Fungal remains, especially ascospores and hypha, are common. Most of the ascospores found are highly melanised and thick-walled and therefore more easily preserved under conditions of oxidation than many pollen (for fungal preservation in palynological assemblages see Graham 1962; Blackford 1998). The regular occurrence of spores of the pteridophyte Mohria sp., which is exceptionally thick-walled, as well as the occasionally occurring pollen of Cyperaceae and Spirostachys africana, might signal local moisture, for example close to a streambank (Roux 1990; Coates-Palgrave 2002).

Phytoliths are present in all sediment samples analysed but are generally scanty. Counts of whole microscope slides did not yield the minimum requirement of 200 phytoliths for meaningful interpretation apart from the sample taken at $90 \mathrm{~cm}$ (MSA deposits). The identifiable phytolith morphotypes are those typical of monocotyledonous plants i.e. grasses (Poaceae) and sedges (Cyperaceae), although some ubiquitous types can also occur in woody plants (Fig. 17). Globular to conical morphotypes that always appears brown were observed (Fig. 17j). Globular phytoliths are associated with woody and herbaceous dicotyledonous plants. For South Africa, this type was illustrated in MSA deposits from Sibudu Cave in KwaZulu-Natal where they were termed 'irregular globular brown bodies' occurring as singular or paired bodies (Murungi 2017). Their overall morphology and the fact that they often appeared articulated are reminiscent of sedge cone phytoliths, and they are thought to be sedge cones distorted by heat (Murungi 2017). These morphotypes are also similar to phytoliths in Restionaceae plants that are typical and mainly restricted to the Fynbos Biome (Cordova 2013; Esteban et al. 2017a, b; Novello et al. 2018). This resemblance between the sedge cones and some restio phytoliths was noted by Cordova (2013). We therefore do not interpret it in this study, since it is not clear which plants it might represent in the Savanna Biome but note that this morphotype occurs at other sites in the region e.g. at Bushman Rock Shelter. While some phytoliths appear broken (Fig. 17a), they also seem to have undergone dissolution and were likely affected by post- 
Table 8 Pollen counts of trees and shrubs in the southern profile inside the test-trench

\begin{tabular}{|c|c|c|c|c|c|c|c|}
\hline Depth & $\begin{array}{l}\text { Euclea } \\
\text { sp. }\end{array}$ & $\begin{array}{l}\text { Olea } \\
\text { sp. }\end{array}$ & Combretaceae & $\begin{array}{l}\text { Spirostachys } \\
\text { africana }\end{array}$ & $\begin{array}{l}\text { Dombeya } \\
\text { sp. }\end{array}$ & $\begin{array}{l}\text { Peltophorum } \\
\text { africanum }\end{array}$ & $\begin{array}{l}\text { Burkea } \\
\text { africana }\end{array}$ \\
\hline $10 \mathrm{~cm}$ & & 2 & & & & 1 & 1 \\
\hline \multicolumn{8}{|l|}{$26 \mathrm{~cm}$} \\
\hline \multicolumn{8}{|l|}{$40 \mathrm{~cm}$} \\
\hline $64 \mathrm{~cm}$ & & 1 & & 1 & 1 & & \\
\hline $76 \mathrm{~cm}$ & & 2 & 1 & & & & \\
\hline $90 \mathrm{~cm}$ & 1 & & & & & & \\
\hline
\end{tabular}

depositional processes, which made it difficult to confidently determine some morphotypes (e.g. Fig. 17k, 1).

\section{Olieboomspoort, the Pietersburg and the MSA in the Savanna Biome}

Mason's excavation of OBP yielded a rich lithic assemblage that he attributed to the middle phase of the so-called Pietersburg and that was instrumental in his characterisation of this industry (Mason 1957, 1959, 1962). Together with OBP, recent work at Bushman Rock Shelter (Porraz et al. 2018) and Mwulu's Cave (de la Peña et al. 2019) has reawakened interest in this somewhat forgotten MSA industry. Between its first mention by E.G. Paterson in the 1920 s (Sampson 1974) and then later in the 1970s, the artefacts of more than 60 sites were attributed to the Pietersburg, including rock shelters and caves, alongside many open-air localities (Mason 1962; Sampson 1974; Fig. 18). We refer to Porraz et al. (2018) and de la Peña et al. (2019) for recent historiographic accounts of this industry. Here, we highlight several problematic aspects related to the exact nature of the Pietersburg, which transpire in renewed discussions on this topic (Wadley et al. 2016; Porraz et al. 2018; de la Peña et al. 2019; Chazan et al. 2020; Feathers et al. 2020).

The ongoing analysis of the lithic assemblage recovered from the MSA deposits of OBP aims to contribute to the evaluation of the Pietersburg's validity as a pertinent and distinct chrono-cultural phase in the southern African MSA. To understand the confusion existing in the literature regarding what exactly the Pietersburg is, it is worth remembering that when it was initially proposed (Goodwin and van Riet Lowe 1929; van Riet Lowe 1940) and later further subdivided (Mason 1957, 1959, 1962), the Pietersburg was envisioned as a regional expression of the MSA as a whole. In other words, the Pietersburg was synonymous with the MSA itself in the former Transvaal region. In fact, every single MSA site excavated there between 1929 and the publication of Volman's synthesis in 1984 was attributed to the Pietersburg, without exception (see Table 11 in the Appendix). In some cases, notably at Border Cave and Wonderwerk Cave, initial attributions to the Pietersburg (Cooke et al. 1945; Beaumont et al. 1978; Beaumont et al. 2006) were later replaced respectively by the MSA 1 , following Volman (1984), and by the Early MSA (Grün and Beaumont 2001; Grün et al. 2003; Chazan et al. 2020). Until recently (Porraz et al. 2018; Feathers et al. 2020), the only numerical ages available for lithic assemblages attributed to the Pietersburg came from a single site, Border Cave. Interestingly, a series of more than 25 ages obtained by ESR dates the lowermost deposits of Border Cave from ca. 227 to ca. 80 ka (Grün and Beaumont 2001; Grün et al. 2003; Table 11 in the Appendix), a chronological range equivalent to more than half of the MSA. The conflation between the Pietersburg and the MSA itself is illustrated by the (albeit limited) existing chronological information, which includes dates from Wonderwerk Cave and Border Cave, going back to the beginning of MIS7 (Grün et al. 2003; Chazan et al. 2020), and more recent dates from the end of MIS5 at Bushman Rock Shelter (Porraz et al. 2018) and Mwulu's Cave (Feathers et al. 2020). When considering the questionable radiocarbon age of Lion Cavern in the MIS3 at $43.2 \mathrm{ka}$
Table 9 Pollen counts of herbs and shrublets in the southern profile inside the test-trench

\begin{tabular}{|c|c|c|c|c|c|c|}
\hline Depth & Poaceae & Asteraceae & Commelinaceae & Chenopodiaceae & Crassula sp. & Cyperaceae \\
\hline $10 \mathrm{~cm}$ & 1 & & & & 1 & \\
\hline \multicolumn{7}{|l|}{$26 \mathrm{~cm}$} \\
\hline $40 \mathrm{~cm}$ & & & & 1 & 1 & \\
\hline $64 \mathrm{~cm}$ & 3 & & 1 & & & 1 \\
\hline $76 \mathrm{~cm}$ & 3 & 1 & & & & 1 \\
\hline $90 \mathrm{~cm}$ & & & & & & 1 \\
\hline
\end{tabular}


Table 10 Counts of spores of pteridophytes, algal cysts and fungal remains (undiff.: undifferentiated), and Varia (crumpled and/or corroded pollen) in the southern profile inside the test-trench

Depth Mohria sp. Trilete spore Monolete spore Pseudo-schizoaea sp. Fungal spores (undiff.) Media-verrunitis sp. Glomus sp. Hypha Varia

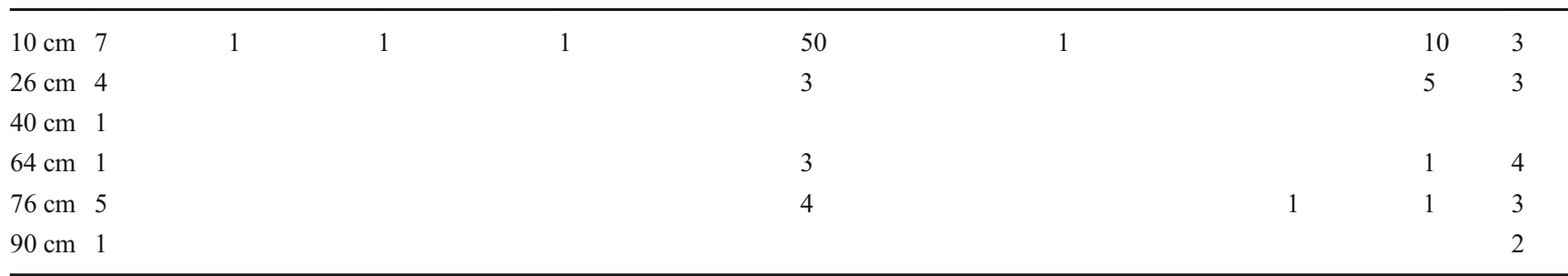

BP (Vogel 1970), the full duration of the Pietersburg broadly equates with that of the MSA in southern Africa. As already pointed out by de la Peña et al. (2019), this explains the difficulties in trying to identify idiosyncratic techno-typological features of the Pietersburg. Most of the elements mentioned are common characteristics of MSA technology (e.g. prepared cores, blade and flake production, Levallois products including Levallois points and facetted platforms). The earlier stage of the Pietersburg, consistent with Bed IV of Cave of Hearths (Mason 1962), could relate to the Early MSA and to Volman's (1984) MSA 1. We suggest that in the literature, the Pietersburg is, at times, equated with the Earlier Pietersburg as conceived by Mason (1962). For instance, the mention of the large dimensions of blanks sometimes occurs in association with the Pietersburg (e.g. Wadley 2015), even though this mostly applied to the early stage (Mason 1957; Eloff 1969).
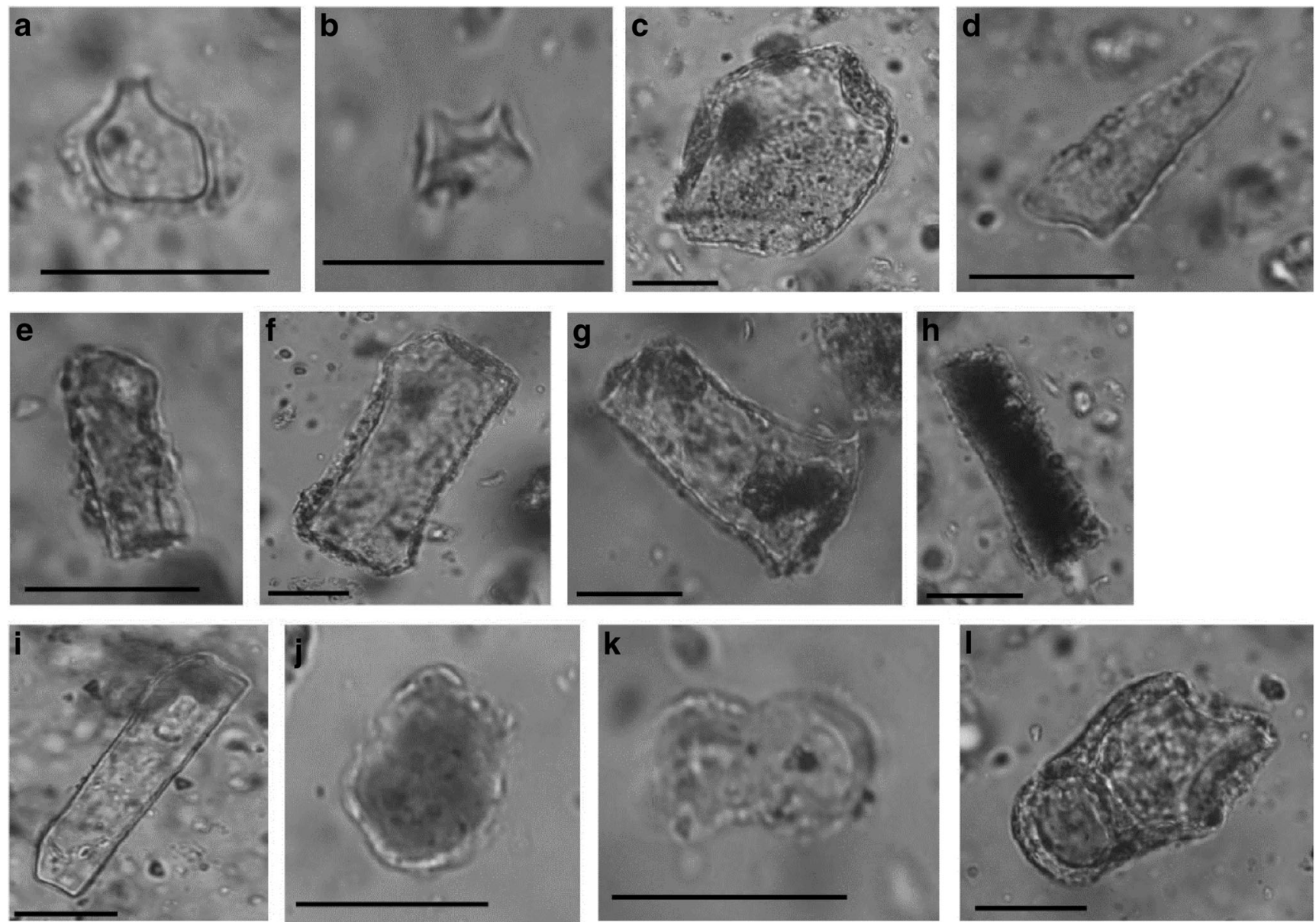

Fig. 17 Grass short cells: broken bilobate (a) and rondel (b). Grass bulliform type (c). Grass acicular hair cell (d). Blocky phytoliths (e, (f and g). Elongate: $\mathbf{h}$ and i. Globular/conical (j). Undetermined types from dissolution: $\mathbf{k}$ and $\mathbf{I}$ ( $\mathbf{l}$ is likely an articulated grass bulliform type). Scale bar is $20 \mu \mathrm{m}$ (pictures M. Murungi) 


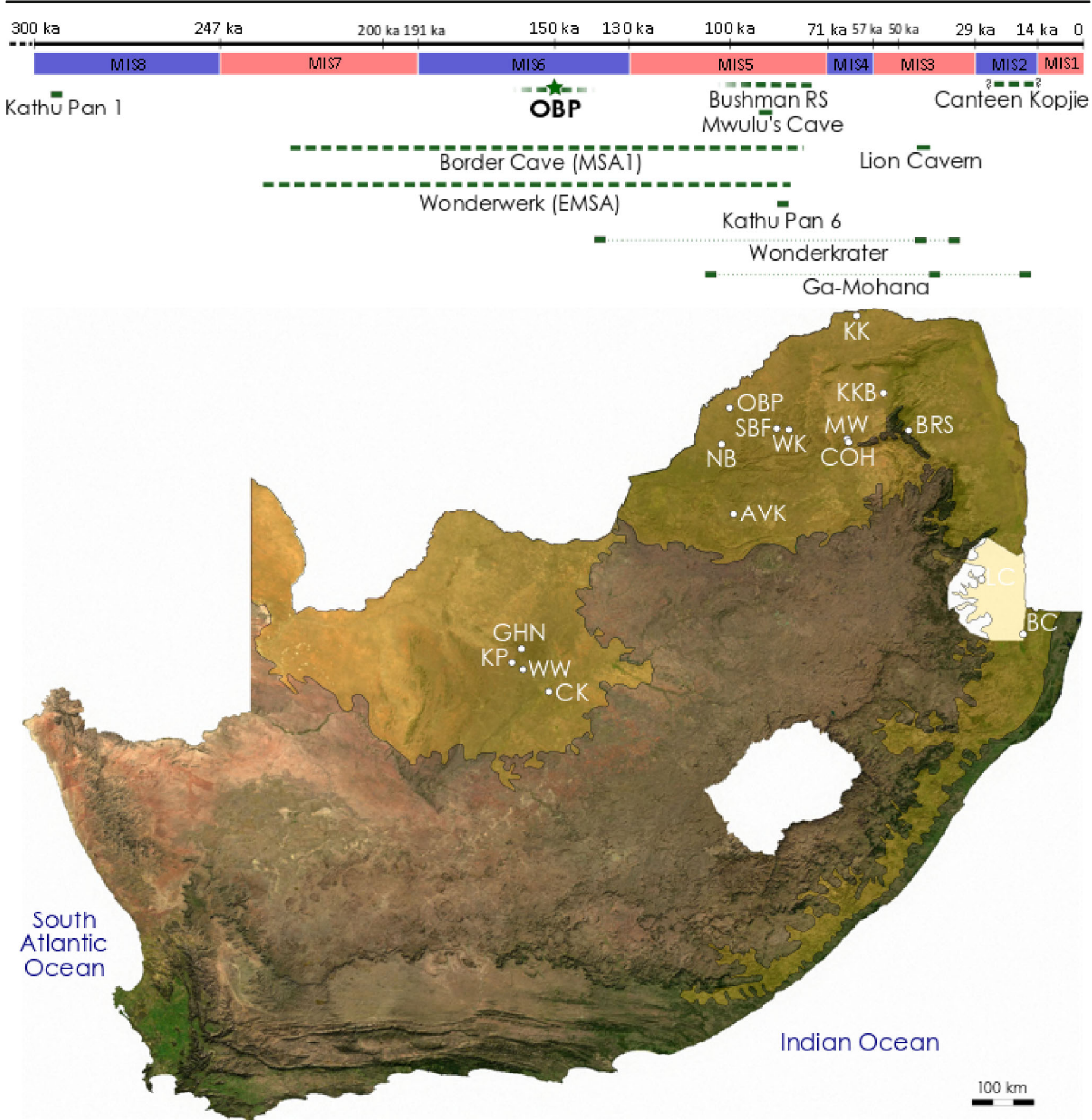

Fig. 18 Map of MSA sites located in the Savanna Biome (in light yellow) of South Africa, with existing dates for site occupation phases in this biome and the new dates for OBP. Abbreviations for site names are the following: AVK for Aasvoëlkop; BRS for Bushman Rock Shelter; CK for Canteen Kopje; $\mathrm{COH}$ for Cave of Hearths; GHN for Ga-Mohana Hill
North Rockshelter; KK for Kudu Koppie; KKB for Kalkbank; KP for Kathu Pan; LC for Lion Cavern; MW for Mwulu's Cave; NB for North Brabant; OBP for Olieboomspoort; SBF for Steenbokfontein; WK for Wonderkrater; and WW for Wonderwerk Cave
Elongated unifacial points and bifacial points are also associated with the Pietersburg in the literature (McBrearty and Brooks 2000; Wadley 2015). They seem to occur in assemblages attributed to the Middle-Late Pietersburg, such as that from Mwulu's Cave (Tobias 1949; de la Peña et al. 2019) and from the upper MSA deposits of Bushman Rock Shelter (Eloff 1969; Plug 1981; Porraz et al. 2018).

Pietersburg localities are limited to the Savanna Biome (Mason 1957, 1962; Fig. 18; Table 11 in the Appendix) and, conversely, the majority of MSA sites in this biome are 
attributed to the Pietersburg. Exceptions to this rule include sites with lithic assemblages that were not diagnostic enough to go beyond a general MSA attribution, such as those from Wonderkrater, Kudu Koppie, Kathu Pan 1 and Steenbokfontein 9KR (Porat et al. 2010; Pollarolo et al. 2010; Backwell et al. 2014; Wadley et al. 2016; Table 11 in the Appendix). Another two exceptions are Canteen Kopje, which has a terminal MSA/early LSA assemblage (Chazan et al. 2013), and Kathu Pan 6 (Feathers 2015), the only Howiesons Poort site in the Savanna Biome.

Our recent work at OBP adds new chrono-stratigraphic data to the ongoing discussion regarding the so-called Pietersburg Industry. The dating of two equid teeth from the MSA deposits to MIS6 means that human visits at OBP are sub-contemporaneous with some of the MSA 1/Early MSA deposits at Wonderwerk (Chazan et al. 2020) and Border Cave (Grün and Beaumont 2001), as well as with the oldest MSA deposits from Wonderkrater (Backwell et al. 2014). The upper part of the MSA sequence at Bushman Rock Shelter dates to MIS5 with the oldest luminescence age on feldspar at $97 \mathrm{ka}$ (Porraz et al. 2018) for a unit that overlies another $\sim 3 \mathrm{~m}$ of sediment. The lowermost deposits from the site might be as old at MIS6.

At OBP, our ongoing reappraisal of site formation processes underlines the possibility that the dense archaeological assemblage results from significant time averaging. The teeth dated were found next to each other and likely belong to the same individual, which explains the consistency between age results for both specimens. This notwithstanding, the length of time represented by the MSA deposits at the site is unclear. Repeated occupations, over the course of millennia or tens of millennia, would have produced accumulations of lithics and ochre pieces within sediments later on affected by deflation, winnowing and bioturbation. Using a quantitative and morphological approach, Mason subdivided the Pietersburg into an Earlier, a Middle and a Later Pietersburg, using percentages of 'primary classes'. These primary classes include quadrilateral, triangular and irregular flakes and Mason considered their dimensions, the raw materials used and their varying proportions between several assemblages to tease apart the three successive stages, using Cave of Hearths as the site reference (Mason 1957, 1962). Olieboomspoort was the second largest lithic assemblage included in his statistical study and he attributed it to the Middle stage of the Pietersburg (Mason 1957). Our understanding of the MSA deposits based on renewed geoarchaeological work at the site weakens the relevance of using proportions of artefact classes from the unstratified OBP deposits to characterise a specific chrono-cultural phase of the MSA.

In-depth analytical work on site formation processes is needed. This work, which includes fabric analysis, is underway, while the taphonomic analysis of the faunal assemblage will also help to clarify the relationship between cultural and organic remains. The analysis of the OBP lithic assemblage will shed light on MIS6 technology and raw material provisioning strategies in the Waterberg, a region where limited information exists on human occupation during the MSA. The only other site excavated in the Waterberg is North Brabant (Schoonraad and Beaumont 1968; Table 11 in the Appendix), a rock shelter that preserves a similar cultural sequence to OBP, with undated MSA deposits capped by LSA deposits with Bambata pottery. The placement of the MSA occupations of OBP within MIS6 is interesting because it is consistent with a glacial stage where arid conditions would have prevailed on the edge of the Kalahari Basin. Pollen data from the deepest part of the Tswaing Crater and attributed to the Middle Pleistocene (ca. 190-150 ka) indicates two dry and moderately warm phases characterised by open grassland savanna alternating with two cooler and wetter phases (Scott 1999). The geographical position of OBP and its rich archaeological assemblage offer the possibility to explore early human adaptations to semi-arid environments.

Moving away from the Pietersburg, we suggest that vegetation biomes, as defined in Mucina and Rutherford (2006), could represent pertinent scales to start building models of human behavioural evolution in southern Africa. Thus, MSA technological developments could be regarded as ecologically variable, associated with the specific climatic, environmental and geological conditions of the different biomes in the region. Mason (1962) proposed that the replacement of late ESA industries by MSA technologies was associated with the emergence of distinct regional cultures in southern Africa; an idea later developed by Clark (1988) for East Africa. The Savanna Biome in South Africa, where OBP is situated, represents the southernmost extension of what is today the largest biome in Africa (Mucina and Rutherford 2006). Based on existing archaeological data for this biome, there is a lack of sites dated to the final MIS5 (after $\sim 80 \mathrm{ka}$ ) and the MIS4 (Fig. 18). This chronological interval is associated with technological innovations and the diffusion of symbolic practices in coastal and near-coastal sites, which might correlate with the expansion of modern humans' ecological niche to the coastal regions of South Africa. A slightly different scenario is that modern humans occupying the interior prior to that time were already adapting their subsistence strategies and developing new behaviours in response to the changing conditions of the interior. Having already adapted to changing ecological conditions inland, modern humans were not simply able to expand into new ecological niches along the coastal regions. By the time their presence is documented at ca. $100 \mathrm{ka}$ along the coast (with the exception of older 
occupations at Pinnacle Point and Elands Bay Cave), they were thriving in parts of the southern Africa shoreline that were ecologically very different. These include the open and relatively dry West Coast all the way up to the subtropical forests of Sibudu Cave. In other words, archaeological evidence for innovations found at coastal and near-coastal sites would represent one visible 'end-product' of a cumulative process that started with the emergence of Anatomically Modern Humans ca. 300 ka ago (e.g. Hublin et al. 2017; Scerri et al. 2018). Our ability to test such hypotheses rests on the quality of the archaeological data and we hope to contribute to this with the new project at OBP, by adding new data on the human occupation of the southern African interior.

\section{Perspectives and conclusion}

Almost 60 years ago, the large lithic assemblage retrieved from Olieboomspoort (OBP) was instrumental in characterising MSA techno-cultural developments in the interior of southern Africa generally and central to Mason's definition of the so-called Pietersburg Industry specifically (Mason 1957, 1959, 1962). The OBP site in the Waterberg mountain range of Limpopo Province is one of the few sites in South Africa preserving a succession of ESA (Acheulean), MSA and Holocene LSA occupation phases, attesting to the long presence of hominins in the area. Recent work by van der Ryst (2007) has highlighted the significance of OBP for understanding the complex interactions between late LSA hunter-gatherers and the first groups of farmers and herders moving into the area in the last two millennia. In this paper, we aimed, first, to provide some historical background to past research at the site and existing data on the chrono-cultural sequence and, second, to introduce a new, multi-disciplinary, field-orientated project that started at OBP in 2018.

Preliminary sampling for pollen and phytolith content of the LSA and MSA deposits illustrates poor preservation of the microscopic organic fraction. One of the MSA samples, however, showed good phytolith preservation and would justify expanding phytolith extraction from the lowermost deposits. The recovery of abundant and relatively well-preserved faunal remains was not expected since the occurrence of animal remains in the MSA deposits had not previously been documented. Preliminary identifications highlight the presence of open habitats (grassland/woodland savanna) and the proximity of a perennial body of water. Future taphonomic analyses of the faunal assemblage combined with taxonomic attributions will strengthen our understanding of site formation processes as well as enable us to propose more refined palaeoenvironmental reconstructions.
While the MSA deposits at OBP preserve abundant archaeological material, including numerous lithic artefacts, ochre pieces and faunal remains, suggesting the repeated use of the shelter, possibly over long periods of time, they are also characterised by some degree of deflation and an unclear stratigraphy. These deposits seem to have suffered from various depositional and post-depositional processes that have affected the preservation of stratified layers. This will hinder its potential for investigating domestic spatial archaeology and this initial aspect of the project will have to be reconsidered. Another initial goal was to identify which geogenic, biogenic and anthropogenic agents played a role at the site and to evaluate their respective impacts on the integrity of the deposits and associated archaeological assemblages. One significant result from our initial fieldwork at the site is that the bedrock is deeper than expected. Further investigation is needed to estimate the depth and characterise the archaeological content of these unexplored archaeological deposits. This also questions the stratigraphic placement of the ESA tools recovered by previous excavations. There is no archaeological data supporting the hypothesis of distinct Acheulean deposits. Rather, these isolate tools seem mixed within MSA deposits. They could have been reworked into more recent deposits or recycled by the MSA occupants of the shelter.

While known since the early 1950 s, OBP progressively stopped featuring in syntheses and comparative MSA techno-typological studies, primarily due to the lack of a chronological framework. CombinedU-series andESR dating of two equid teeth from the newly excavated MSA deposits provided for the first time a direct mean age of $150 \pm 14 \mathrm{ka}(1 \sigma)$ for these fossils. We expect to obtain additional and independent age constraints for the deposits from the currently ongoing luminescence dating study. Although we acknowledge the existing uncertainty around these ESR age estimates in the absence of in situ dosimetry, there are currently no other dated MSA sites in the Waterberg. How much variations in the extension of the Kalahari Basin affected Middle to Late Pleistocene human occupations of this part of South Africa remains to be explored. Refining the chronological framework of the MSA deposits is the first step in facilitating comparisons between the technological characteristics of the abundant lithic assemblage from OBP and those from other MSA sites in the region, including Mwulu's Cave, Bushman Rock Shelter and Cave of Hearths. We acknowledge here the pioneering work of Revil Mason in clarifying the techno-cultural successions in the southern African interior. Our work at OBP confirms, however, that the so-called Pietersburg, as it stands, does not represent a clear chrono-cultural unit. With future work at the site and on the material, we hope to contribute to an ongoing, collective effort of refining our understanding of the specificities of the cultural dynamics in the Savanna Biome during the Middle to Late Pleistocene. 


\section{Appendix}

Table 11 MSA sites located in the Savanna Biome of South Africa and Swaziland, with existing chronology and dating methods used (OSL optically stimulated luminescence, ESR electron spin resonance, $U$-series uranium-series), cultural attributions and associated literature references

\begin{tabular}{|c|c|c|c|c|}
\hline Site & Type & Chronology; method & Cultural attribution & References \\
\hline Aasvoëlkop & Hilltop rubble & - & Middle Pietersburg & Mason 1957 \\
\hline Border Cave & Rock shelter & $227 \pm 11-77 \pm 2 \mathrm{ka} ; \mathrm{ESR}$ & $\begin{array}{l}\text { Middle and Later } \\
\text { Pietersburg/MSA1 }\end{array}$ & $\begin{array}{l}\text { Beaumont et al. 1978; Grün } \\
\text { et al. } 2003\end{array}$ \\
\hline $\begin{array}{l}\text { Bushman Rock } \\
\text { Shelter }\end{array}$ & Rock shelter & $\overline{-} 97 \pm 10 \mathrm{ka}-73 \pm 6 \mathrm{ka} ;$ OSL & $\begin{array}{l}\text { Earlier Pietersburg } \\
\text { Middle and Later Pietersburg }\end{array}$ & $\begin{array}{l}\text { Eloff } 1969 \\
\text { Porraz et al. } 2018\end{array}$ \\
\hline Canteen Kopje & River gravel site & $\begin{array}{l}\text { Late Pleistocene/early Holocene }(<25 \\
\text { ka); OSL }\end{array}$ & Terminal MSA/early LSA & Chazan et al. 2013 \\
\hline Cave of Hearths & Cave & - & $\begin{array}{l}\text { Earlier, Middle and Later } \\
\text { Pietersburg }\end{array}$ & Mason 1962 \\
\hline Goergap $113 \mathrm{KR}$ & Rock shelter & - & Undiagnostic MSA & van der Ryst 1998 \\
\hline Kalkbank & Open-air & - & Later Pietersburg & $\begin{array}{l}\text { Mason 1962; Hutson \& Cain } \\
\quad 2008\end{array}$ \\
\hline Kathu Pan 1 & Open-air doline & $291 \pm 45 \mathrm{ka} ;$ OSL & MSA & Porat et al. 2010 \\
\hline \multirow[t]{2}{*}{ Kathu Pan 6} & Open-air doline & - & Early MSA & Lukich et al. 2019 \\
\hline & & $79.4 \pm 8.1 \mathrm{ka} ;$ OSL & Howiesons Poort & Feathers 2015 \\
\hline Koedoesrand & Hilltop rubble & - & Earlier Pietersburg & Mason 1957 \\
\hline Kudu Koppie & Sandstone outcrop & - & MSA (with bifacial points) & Pollarolo et al. 2010 \\
\hline Lion Cavern & Rock shelter & $43.2+1350 /-1200 \mathrm{ka}$ BP; radiocarbon & Middle Pietersburg & Vogel 1970; Sampson 1974 \\
\hline Mwulu's Cave & Rock shelter & $\sim 90 \mathrm{ka} ;$ OSL & Middle Pietersburg & $\begin{array}{l}\text { Tobias } 1949 \text {; Feathers et al. } \\
\quad 2020\end{array}$ \\
\hline North Brabant & Rock shelter & - & Middle Pietersburg & $\begin{array}{l}\text { Schoonraad and Beaumont } \\
1968\end{array}$ \\
\hline Olieboomspoort & Rock shelter & - & Middle Pietersburg & Mason 1962 \\
\hline Rufus & Rock shelter & & Later Pietersburg & Mason 1962 \\
\hline Skoonheid 1529 & Open-air site & - & $\begin{array}{l}\text { Earlier, Middle and Later } \\
\text { Pietersburg }\end{array}$ & Mason 1957, 1959 \\
\hline $\begin{array}{l}\text { Steenbokfontein } \\
\quad 9 \mathrm{KR}\end{array}$ & Spring site & - & Undiagnostic MSA & Wadley et al. 2015 \\
\hline Waterwal & Natural terrace & - & Middle Pietersburg & Partridge 1964 \\
\hline Wonderkrater & $\begin{array}{l}\text { Spring and mound } \\
\text { site }\end{array}$ & $30 \mathrm{ka} ;>45 \mathrm{ka} ; 138.01 \pm 7.7 \mathrm{ka} ;$ OSL & Undiagnostic MSA & Backwell et al. 2014 \\
\hline Wonderwerk Cave & Cave & $\begin{array}{l}220 \pm 14-78 \pm 4 \mathrm{ka} ; \text { U-series } \\
240-150 \mathrm{ka} ; \text { TT-OSL }\end{array}$ & $\begin{array}{l}\text { Middle-Later Pietersburg } \\
\text { Early MSA }\end{array}$ & $\begin{array}{l}\text { Beaumont and Vogel } 2006 \\
\text { Chazan et al. } 2020\end{array}$ \\
\hline
\end{tabular}

Acknowledgements We are greatly indebted to Francois Coetzee from the Museum of Anthropology and Archaeology at UNISA for his support since the beginning of this project and for facilitating access to the R. Mason and M. van der Ryst's collections. We would like to thank the Evolutionary Studies Institute for curatorial space and field equipment. Our acknowledgements go to Bernhard Zipfel and Marion Bamford in that institution. We thank SAHRA for the excavation permit. The support of the DST/NRF Centre of Excellence in Palaeosciences (CoE in Palaeosciences) towards this research is hereby acknowledged. Aspects of the U-series and ESR dating study have been funded by the Australian Research Council Future Fellowship Grant FT150100215 and the Spanish Ramón y Cajal Fellowship RYC2018-025221-I. We thank María Jesús Alonso Escarza and Javier Iglesias Cibanal, CENIEH, for technical support throughout the analytical procedure. We are extremely grateful to Andries and Dirk Beukes for allowing us to access the site located on their farm and being supportive of the research project. We would like to thank Lyn Wadley for her continuous scientific support and early discussions on the site and the project. We wish to thank the late Revil Mason, with whom we had fruitful discussions about his research at the site before starting our own fieldwork. We would like to thank Prosper Bande at the Evolutionary Studies Institute for preparing the pollen and phytolith samples. Studies at the Olieboomspoort site and archaeological material will not be possible without the volunteers who helped during the fieldwork and we express here special thanks to Annina Deirdre van Neel, Rose Emily, Tumelo Molefyane, Humphrey Nyambiya, Byron Jones and Wim Biemond.

Funding Open Access funding enabled and organized by Projekt DEAL. 


\section{Declarations}

Conflict of interest The authors have no competing interests.

Disclaimer Opinions expressed and conclusions arrived at are those of the authors and are not necessarily to be attributed to the CoE in Palaeosciences.

Open Access This article is licensed under a Creative Commons Attribution 4.0 International License, which permits use, sharing, adaptation, distribution and reproduction in any medium or format, as long as you give appropriate credit to the original author(s) and the source, provide a link to the Creative Commons licence, and indicate if changes were made. The images or other third party material in this article are included in the article's Creative Commons licence, unless indicated otherwise in a credit line to the material. If material is not included in the article's Creative Commons licence and your intended use is not permitted by statutory regulation or exceeds the permitted use, you will need to obtain permission directly from the copyright holder. To view a copy of this licence, visit http://creativecommons.org/licenses/by/4.0/.

\section{References}

Ames CJH, Gliganic L, Cordova CE, Boyd K, Jones BG, Maher L, Collins B (2020) Chronostratigraphy, site formation, and palaeoenvironmental context of Late Pleistocene and Holocene occupations at Grassridge Rock Shelter (Eastern Cape, South Africa). Open Quat 6(5):1-19

Barker H, Mackey CJ (1959) British Museums natural radiocarbon measurements I. Am J Sci Radiocarbon Suppl 1:81-86

Backwell L, d'Errico F, Wadley L (2008) Middle Stone Age bone tools from the Howiesons Poort layers, Sibudu Cave, South Africa. J Archaeol Sci 35:1566-1580

Backwell LR, McCarthy TS, Wadley L, Henderson Z, Steininger CM, de Klerk B, Barré M, Lamothe M, Chase BC, Woodborne S, Susino GJ, Bamford MK, Sievers C, Brink JS, Rossouw L, Pollarolo L, Trower G, Scott L, d'Errico F (2014) Multiproxy record of late Quaternary climate change and Middle Stone Age occupation at Wonderkrater, South Africa. Quat Sci Rev 99:42-59

Backwell LR, d'Errico F, Banks WE, de la Peña P, Sievers C, Stratford D, Lennox SJ, Wojcieszak M, Bordy EM, Bradfield J, Wadley L (2018) New excavations at Border Cave, KwaZulu-Natal, South Africa. J Field Archaeol 43:417-436. https://doi.org/10.1080/ 00934690.2018 .1504544

Badenhorst S, Plug I (2012) The faunal remains from the Middle Stone Age layers of Bushman Rock Shelter in South Africa. S Afr Archaeol Bull 67:16-31

Blackford JJ (1998) Fungal spores and other microfossils. In: Preece RC, Bridgland DR (eds) Late Quaternary environmental change in North-West Europe: excavations at Holywell Coombe, South-East England. Springer, Dordrecht, pp 149-157

Beaumont PB, Vogel JC (2006) On a timescale for the past million years of human history in central South Africa. S Afr J Sci 102:217-228

Beaumont PB, de Villiers H, Vogel JC (1978) Modern man in subSaharan Africa prior to 49000 years B.P.: a review and evaluation with particular reference to Border Cave. S Afr J Sci 74:409-419

Boëda E (1993) Le débitage discoïde et le débitage Levallois récurrent centripède. Bull Soc Préhist Fr 90:392-404

Boëda E (1994) Le concept Levallois: variabilité des méthodes. Archéo éditions
Brain CK, Cooke CK (1967) A preliminary account of the Redcliffe Stone Age cave site in Rhodesia. S Afr Archaeol Bull 21(84):171182

Brain CK, Cooke CK (1967) A preliminary account of the Redcliffe Stone Age cave site in Rhodesia. S Afr Archaeol Bull 21(84):171182

Brandl G (1996) The geology of the Ellisras area. Council for Geoscience. Explanation of Sheet 2326 (1:250 000)

Butzer KW (1984) Archaeology and Quaternary environment in the interior of southern Africa. In: Klein RG (ed) Southern African prehistory and paleoenvironments. A.A. Balkema, Rotterdam, pp 1-64

Carter PL (1976) The effects of climate change on settlement in eastern Lesotho during the Middle and Later Stone Age. World Archaeol 8: 197-206

Clark DJ (1988) The Middle Stone Age of East Africa and the beginnings of regional identity. J World Prehist 2(3):235-305

Clark TR, J-x Z, Roff G, Feng Y-X, Done TJ, Nothdurft LD, Pandolfi JM (2014) Discerning the timing and cause of historical mortality events in modern Porites from the Great Barrier Reef. Geochim Cosmochim Acta 138:57-80

Chazan M, Porat N, Sumner AT, Horwitz LK (2013) The use of OSL dating in unstructured sands: the archaeology and chronology of the Hutton Sands at Canteen Kopje (Northern Cape Province, South Africa). Archaeol Anthropol Sci 5:351-363

Chazan M, Ron A, Matmon A, Porat N, Goldberg P, Yates R, Avery M, Sumner A, Horwitz LK (2008) Radiometric dating of the Earlier Stone Age sequence in Excavation I at Wonderwerk Cave, South Arica: preliminary results. J Hum Evol 55:1-11

Chazan M, Berna F, Brink J, Ecker M, Holt S, Porat N, Lee Thorp J, Horwitz LK (2020) Archeology, environment, and chronology of the Early Middle Stone Age component of Wonderwerk Cave. J Paleol Archaeol 3:302-335. https://doi.org/10.1007/s41982-02000051-8

Cheng H, Edwards RL, Hoff J, Gallup CD, Richards DA, Asmerom Y (2000) The half-lives of uranium-234 and thorium-230. Chem Geol 169:17-33

Churcher CS (2006) Distribution and history of the Cape zebra (Equus capensis) in the Quaternary of Africa. Trans Roy Soc SAfr 61(2): 89-95

Coates-Palgrave M (2002) Trees of southern Africa. $3^{\text {rd }}$ edn, $2^{\text {nd }}$ imp. Struik Publishers, Cape Town

Codron D, Brink JS, Rossouw L, Clasuss M (2008) The evolution of ecological specialisation in southern African ungulates: competition or physical environmental turnover. Oikos 117:334-353

Cooke CK (1963) Report on excavations at Pomongwe and Tshangula Caves, Matopos Hills, southern Rhodesia. S Afr Archaeol Bull 18(71):73-151

Cooke CK (1971) Excavations in Zombepata Cave, Sipolilo District, Mashonaland, Rhodesia. S Afr Archaeol Bull 26(103/104):104-126

Cooke HBS, Malan BD, Wells LH (1945) Fossil Man in the Lebombo Mountains, South Africa: The 'Border Cave,' Ingwavuma District, Zululand. Man 45:6-13

Cooper RL, Skinner JD (1979) Importance of termites in the diet of the Aardwolf Proteles cristatus in South Africa. S Afr J Zool 14(1):5-8

Cordova CE (2013) C3 Poaceae and Restionaceae phytoliths as potential proxies for reconstructing winter rainfall in South Africa. Quat Int 293:121-140

De la Torre I (2016) The origins of the Acheulean: past and present perspectives on a major transition in human evolution. Phil Trans Roy Soc B: Biol Sci 371(1698):20150245

d'Errico F, Henshilwood CS, Vanhaeren M, van Niekerk K (2005) Nassarius kraussianus shell beads from Blombos Cave: evidence for symbolic behaviour in the Middle Stone Age. J Hum Evol 48:2 14 
d'Errico F, Vanhaeren M, Wadley L (2008) Possible shell beads from the Middle Stone Age layers of Sibudu Cave, South Africa. J Archaeol Sci 35:2675-2685

d'Errico F, García Moreno R, Rifkin RF (2012) Technological, elemental and colorimetric analysis of an engraved ochre fragment from the Middle Stone Age levels of Klasies River Cave 1, South Africa. J Archaeol Sci 39:942-952

de la Peña P (2015) Refining our understanding of Howiesons Poort lithic technology: the evidence from Grey rocky layer in Sibudu Cave (KwaZulu-Natal, South Africa). PLoS One 10(12):e0143451

de la Peña P, Val A, Stratford D, Colino F, Esteban I, Fitchett JM, Hodgskiss T, Matembo J, Moll R (2019) Revisiting Mwulu's Cave: new insights into the Middle Stone Age in the southern African Savanna biome. Archaeol Anthropol Sci 11:3239-3266. https://doi.org/10.1007/s12520-018-0749-9

Duval M, Grün R (2016) Are published ESR dose assessments on fossil tooth enamel reliable? Quat Geochronol 31:19-27

Duval M, Fang F, Suraprasit K, Jaeger J-J, Benammi M, Chaimanee Y, Iglesias Cibanal J, Grün R (2019) Direct ESR dating of the late Middle Pleistocene vertebrate assemblage from Khok Sung locality, Nakhon Ratchasima Province, Northeast Thailand. Palaeontol Elect 223 69:1-25. https://doi.org/10.26879/941

Eastwood E (2003) A cross-cultural motif in San, Khoekhoe and Northern Sotho rock paintings of the Central Limpopo Basin, southern Africa. S Afr Archaeol Bull 58:14-26

Eastwood EB, Smith BW (2005) Fingerprints of the Khoekhoen: a study of geometric and handprinted rock paintings in the Central Limpopo Basin, southern Africa. In: Blundell G (ed) Further approaches to southern African rock art, Cape Town: S Afr Archaeol Soc Goodwin Series, vol 9, pp 63-76

Eisenmann V (2000) Equus capensis (Mammalia, Perissodactyla) from Elandsfontein. Palaeontol Afr 36:91-96

Eloff JF (1969) Bushman Rock Shelter, Eastern Transvaal: excavations, 1967-8. S Afr Archaeol Bull 24:60

Eriksson PG, Simpson EL, Eriksson KA, Bumby AJ, Steyn GL, Sarkar S (2000) Muddy roll-up structures in siliciclastic interdune beds of the c. $1.8 \mathrm{Ga}$ Waterberg Group, South Africa. Palaios 15:177-183

Esteban I, de Vynck JC, Singels E, Vlok J, Marean CW, Cowling RM, Fisher EC, Cabanes D, Albert RM (2017a) Modern soil phytolith assemblages used as proxies for paleoscape reconstruction on the south coast of South Africa. Quat Int 434:160-179

Esteban I, Vlok J, Kotina EL, Bamford MK, Cowling RM, Cabanes D, Albert RM (2017b) Phytoliths in plants from the south coast of the greater Cape Floristic region (South Africa). Rev Palaeobot Palynol 245:160-179

Esteban I, Fitchett JM, de la Peña P (2020) Plant taphonomy, flora exploitation and palaeoenvironments at the Middle Stone Age site of Mwulu's Cave (Limpopo, South Africa): an archaeobotanical and mineralogical approach. Archaeol Anthropol Sci 12:226. https://doi. org/10.1007/s12520-020-01181-4

Faith JT (2014) Late Pleistocene and Holocene mammal extinctions on continental Africa. Earth-Sci Rev 128:105-121

Feathers J (2015) Luminescence dating at Diepkloof Rock Shelter - new dates from single-grain quartz. J Archaeol Sci 63:164-174

Feathers J, Evans M, Stratford D, de la Peña P (2020) Exploring complexity in luminescence dating of quartz and feldspars at the Middle Stone Age site of Mwulu's Cave (Limpopo, South Africa). Quat Geochronol 59:101092

Goodwin AJH, van Riet LC (1929) The Stone Age cultures of South Africa. Ann S Afr Mus 27:1-289

Graham A (1962) The role of fungal spores in palynology. J Paleontol 36(1):60-68

Groucutt HS, Petraglia MD, Bailey G, Scerri EML, Parton A, ClarkBalzan L, Jennings RP, Lewis L, Blinkhorn J, Drake NA, Breeze PS, Inglis RH, Devès MH, Meredith-Williams M, Boivin N,
Thomas MG, Scally A (2015) Rethinking the dispersal of Homo sapiens out of Africa. Evol Anthropol 24:149-164

Grün R (2000a) Methods of dose determination using ESR spectra of tooth enamel. Radiat Meas 32(5-6):767-772

Grün R (2000b) An alternative model for open system U-series/ESR age calculations: (closed system U-series)-ESR, CSUS-ESR. Ancient TL 18(1):1-4

Grün R (2009) The DATA program for the calculation of ESR age estimates on tooth enamel. Quat Geochronol 4(3):231-232

Grün R, Brumby S (1994) The assessment of errors in past radiation doses extrapolated from ESR/TL dose-response data. Radiat Meas 23(2-3):307-315

Grün R, Katzenberger-Apel O (1994) An alpha irradiator for. ESR Dat Ancient TL 12(2):35-38

Grün R, Schwarcz HP, Chadam J (1988) ESR dating of tooth enamel: Coupled correction for U-uptake and U-series disequilibrium. Int J Radiat App Instrum D Nuclear Tracks Rad Measur 14(1-2):237241

Grün R, Beaumont P (2001) Border Cave revisited: a revised ESR chronology. J Hum Evol 40:467-482

Grün R, Beaumont P, Tobias PV, Eggins S (2003) On the age of Border Cave 5 human mandible. J Hum Evol 45:155-167

Guérin G, Mercier N, Adamiec G (2011) Dose-rate conversion factors: update. Ancient TL 29:5-52

Hall S, Smith B (2000) Empowering places: rock shelters and ritual control in farmer-forager interactions in the Northern Province. In: Leslie M, Maggs T (eds) African Naissance: the Limpopo Valley 1000 years ago, vol 8. S Afr Archaeol Soc Goodwin Series, Cape Town, pp 30-46

Haradon CM (2010) The ecological context of the Acheulean to Middle Stone Age transition in Africa. PhD thesis. George Washington University, Washinton DC

Henn BM, Steele TE, Weaver TD (2018) Clarifying distinct models of modern human origins in Africa. Curr Op Genet \& Dev 53:148-156

Henshilwood CS, d'Errico F, Yates R, Jacobs Z, Tribolo C, Duller GAT, Mercier N, Sealy JC, Valladas H, Watts I, Wintle AG (2002) Emergence of modern human behaviour: Middle Stone Age engravings from South Africa. Science 295:1278-1280

Henshilwood CS, d'Errico F, Vanhaeren M, van Niekerk KL, Jacobs Z (2004) Middle Stone Age shell beads from South Africa. Science 304:404

Henshilwood CS, d'Errico F, van Niekerk KL, Coquinot Y, Jacobs Z, Lauritzen S-E, Menu M, García-Moreno R (2011) A 100,000-yearold ochre-processing workshop at Blombos Cave, South Africa. Science 334:219-222

Hooijer DA (1976) The late Pliocene Equidae of Langebaanweg, Cape Province, South Africa. Zool Verh 48:4-39

Hublin JJ, Ben-Ncer A, Bailey S, Freidline SE, Neubauer S, Skinner MM, Bergmann I, Le Cabec A, Benazzi S, Harvati K, Gunz P (2017) New fossils from Jebel Irhoud, Morocco and the panAfrican origin of Homo sapiens. Nature 546:289-291

Hutson JM, Cain CR (2008) Reanalysis and reinterpretation of the Kalkbank faunal accumulation, Limpopo Province, South Africa. J Taph 6(3-4):399-428

Jacobs Z, Roberts RG, Galbraith RF, Deacon HJ, Grün R, Mackay A, Mitchell P, Vogelsang R, Wadley L (2008) Ages for the Middle Stone Age of Southern Africa: implications for human behavior and dispersal. Science 322:733-735

Keller CM (1973) Montagu Cave in prehistory. Univ Calif Anthropol Rec 28:1-150

Klein RG (1970) Problems in the study of the Middle Stone Age of South Africa. S Afr Archaeol Bull 25(99/100):127-135

Klein RG (1977) The mammalian fauna from the Middle and Later Stone Age (later Pleistocene) levels of Border Cave, Natal Province, South Africa. S Afr Archaeol Bull 32(125):14-27 
Klein RG (1983) The Stone Age Prehistory of Southern Africa. Annu Rev Anthropol 12:25-48

Klein RG (2000) The Earlier Stone Age of Southern Africa. S Afr Archaeol Bull 55:107-122

Kuman K (2016) Development of the archaeological record in southern African during the Earlier Stone Age. In: Knight J, Grab S (eds) Quaternary environmental change in southern Africa: physical and human dimensions. Cambridge University Press, Cambridge, pp 349-370

Lee-Thorp JA, Beaumont PB (1995) Vegetation and seasonality shifts during the late Quaternary deduced from ${ }^{13} \mathrm{C} /{ }^{12} \mathrm{C}$ ratios of grazers at Equus Cave, South Africa. Quat Res 43:426-432

Lisiecki LE, Raymo ME (2005) A Pliocene-Pleistocene stack of 57 globally distributed benthic d18O records. Paleoceanograph 20:PA1003. https://doi.org/10.1029/2004PA001071

Lotter M, Kuman K (2018) The Acheulean in South Africa, with announcement of a new site (Penhill Farm) in the lower Sundays River Valley, Eastern Cape Province, South Africa. Quat Int 480: $43-65$

Ludwig K (2012) Isoplot/Ex, v. 3.75, A Geochronological Toolkit for Microsoft Excel, 5th edn. Berkeley Geochronology Center Special Publication, Berkeley

Lukich V, Cowling S, Chazan M (2020) Palaeoenvironmental reconstruction of Kathu Pan, South Africa, based on sedimentological data. Quat Sci Rev 230:106153

Lukich V, Porat N, Faershtein G, Cowling S, Chazan M (2019) New chronology and stratigraphy for Kathu Pan 6, South Africa. J Paleol Archaeol 2:235-257

Mackenzie G, Boa AN, Diego-Taboada A, Atkin SL, Sathyapalan T (2015) Sporopollenin, the least known yet toughest natural biopolymer. Front Math 2. https://doi.org/10.3389/fmats.2015.00066

Marsh RE (1999) Beta-gradient isochrons using Electron Paramagnetic Resonance: towards a new dating method in archaeology. MSc thesis. McMaster University, Hamilton

Marean CW, Bar-Matthews M, Bernatchez J, Fisher E, Goldberg P, Herries AIR, Jacobs Z, Jerardino A, Karkanas P, Minichillo T, Nilssen PJ, Thompson E, Watts I, Williams HM (2007) Early human use of marine resources and pigment in South Africa during the Middle Pleistocene. Nature 449:905-908

Mason R (1957) The Transvaal Middle Stone Age and statistical analysis. S Afr Archaeol Bull 12(48):119-137

Mason R (1959) Later Pleistocene stratigraphy in the Transvaal and its relation to the East African sequence. S Afr Archaeol Bull 14(53):38

Mason R (1962) Prehistory of the Transvaal. Witwatersrand University Press, Johannesburg

Mason R (1982) Prehistoric mining in South Africa, and Iron Age copper mines in the Dwarsberg, Transvaal. J South Afr Inst Min Metall: 134-142

Mason R (1988) Cave of Hearths, Makapansgat, Transvaal. University of the Witwatersrand, Johannesburg

McBrearty S, Brooks AS (2000) The revolution that wasn't: a new interpretation of the origin of modern human behavior. J Hum Evol 39 (5):453-563

McNabb J, Beaumont PB (2012) Excavations in the Acheulean levels at the Earlier Stone Age site of Canteen Koppie, Northern Province, South Africa. Proc Prehist Soc 78:51-71

Mitchell PJ (1996) The late Quaternary of the Lesotho Highlands, southern Africa: preliminary results and future potential of ongoing research at Sehonghong Shelter. Quat Int 33:35-43

Mitchell P (2002) The Archaeology of southern Africa. Cambridge University Press, Cambridge

Mourre V, Villa P, Henshilwood CS (2010) Early use of pressure flaking on lithic artifacts at Blombos Cave, South Africa. Science 330:659662
Mucina L, Rutherford MC (2006) The vegetation of South Africa, Lesotho and Swaziland. South African National Biodiversity Institute, Pretoria

Murungi ML (2017) Phytoliths at Sibudu (South Africa): implications for vegetation, climate and human occupation during the MSA. PhD thesis. University of the Witwatersrand, Johannesburg

Novello A, Bamford MK, van Wijk V, Wurz S (2018) Phytoliths in modern plants and soils from Klasies River, Cape Region (South Africa). Quat Int 464:440-459

Ouzman S, Smith BW (2004) Southern Africa's Khoekhoen herder rock art. Dig Stick 21(3):1-4

Partridge TC (1964) A Middle Stone Age and Iron Age site at Waterval, North West of Johannesburg. S Afr Archaeol Bull 19(76):102-110

Piperno DR (2006) Phytoliths. A comprehensive guide for archaeologists and paleoecologists. Altamira Press, Lanham, New York, Toronto, Oxford

Plug I (1981) Some Research Results on the Late Pleistocene and Early Holocene Deposits of Bushman Rock Shelter, Eastern Transvaal. S Afr Archaeol Bull 36(133):14-21

Pollarolo L, Wilkins J, Kuman K, Galletti L (2010) Site formation at Kudu Koppie: A late Earlier and Middle Stone Age site in northern Limpopo Province, South Africa. Quat Int 216:151-161

Porat N, Chazan M, Grün R, Aubert M, Eisenmann V, Horwitz LK (2010) New radiometric ages for the Fauresmith industry from Kathu Pan, southern Africa: implications for the Earlier to Middle Stone Age transition. J Archaeol Sci 37:269-283

Porraz G, Val A, Dayet L, de la Peña P, Douze K, Miller CE, Murungi M, Tribolo C, Schmid VC, Sievers C (2015) Bushman Rock Shelter (Limpopo, South Africa): a perspective from the edge of the Highveld. S Afr Archaeol Bull 70(202):166-179

Porraz G, Val A, Tribolo C, Mercier N, de la Peña P, Haaland M, Igreja M, Miller CE, Schmid VC (2018) The MIS5 Pietersburg at '28' Bushman Rock Shelter, Limpopo Province, South Africa. PLoS One 13(10): 0202853

Richard M, Falguères C, Pons-Branchu E, Ghaleb B, Valladas H, Mercier N, Richter D, Bahain J-J, Conard NJ (2017) Datation par les méthodes ESR/U-Th combinées de sites du Pléistocène supérieur : méthodologie et application en contexte karstique. L'Anthropol 121(1):63-72

Richardson PRK (1987) Aardwolf: the most specialized myrmecophagous mammal? S Afr J Sci 83:643-646

Robinson KR (1958) Some Stone Age sites in Inyanga District. Inyanga: Prehistoric Settlements in Southern Rhodesia, pp 270-309

Roux JP (1990) Description of two new species of Mohria (Schizaeaceae: Pteridophyta) from South Africa. S Afr J Bot 56(2):266-270

Sampson G (1974) The Stone Age archaeology of southern Africa. Academic Press, New York

Scerri EML, Thomas MG, Manica A, Gunz P, Stock JT, Stringer C, Grove M, Groucutt HS, Timmermann A, Rightmire GP, d'Errico F, Tryon C, Drake NA, Brooks AS, Dennell RW, Durbin R, Henn BM, Lee-Thorp J, deMenocal P, Petraglia MD, Thompson JC, Scally A, Chikhi L (2018) Did our species evolve in subdivided populations across Africa, and why does it matter? Trends Ecol Evol 33(8):582-594

Scott L (1999) Vegetation history and climate in the Savanna biome South Africa since 190,000 ka: a comparison of pollen data from the Tswaing Crater (the Pretoria Saltpan) and Wonderkrater. Quat Int 57(58):215-223

Scott L, Neumann F (2018) Pollen-interpreted palaeoenvironments associated with the Middle and Late Pleistocene peopling of Southern Africa. Quat Int 495:169-184

Schlebusch CM, Jakobsson M (2018) Tales of human migration, admixture, and selection in Africa. Annu Rev Genomics Hum Genet 19: $10.1-10.24$

Schoonraad M, Beaumont PB (1968) The North Brabant Shelter, north western Transvaal. S Afr J Sci 64:319-331 
Shao Q, Bahain J-J, Falguères C, Dolo J-M, Garcia T (2012) A new Uuptake model for combined ESR/U-series dating of tooth enamel. Quat Geochronol 10:406-411

Shao Q, Bahain J-J, Dolo J-M, Falguères C (2014) Monte Carlo approach to calculate US-ESR age and age uncertainty for tooth enamel. Quat Geochronol 22:99-106

Skinner JD, Chimimba CT (2005) The mammals of the southern African subregion. Cambridge University Press, Cambridge

Stewart B, Dewar G, Morley MW, Inglis RH, Wheeler M, Jacobs Z, Roberts RG (2012) Afromontane foragers of the Late Pleistocene: site formation, chronology and occupational pulsing at Melikane Rockshelter, Lesotho. Quat Int 270:40-60

Texier P-J, Porraz G, Parkington JE, Rigaud J-P, Poggenpoel C, Miller CE, Tribolo C, Cartwright C, Coudenneau A, Klein R, Steele T, Verna C (2010) Howiesons Poort tradition of engraving ostrich eggshell containers dated to 60,000 years ago at Diepkloof Rock Shelter, South Africa. PNAS 107:6180-6185

Texier P-J, Porraz G, Parkington JE, Rigaud J-P, Poggenpoel C, Tribolo C (2013) The context, form and significance of the MSA engraved ostrich eggshell collection from Diepkloof Rock Shelter, Western Cape, South Africa. J Archaeol Sci 40:3412-3431

Tobias PV (1949) The excavation of Mwulu's Cave, Potgietersrust district. S Afr Archaeol Bull 4:2-13

Underhill DR (2011) A history of Stone Age study in South Africa. S Afr Archaeol Bull 66:3-14

van der Ryst MM (1998) The Waterberg plateau in the Northern Province, Republic of South Africa, in the Later Stone Age. BAR Int Ser 715:1-158

van der Ryst MM (2007) Seeking shelter: Later Stone Age hunters, gatherers and fishers of Olieboomspoort in the Western Waterberg, South of the Limpopo. PhD thesis. University of the Witwatersrand, Johannesburg

van Riet LC (1940) The Makapan Caves: an archaeological note. S Afr J Sci 35:371-381

Vogel JC (1970) Groningen radiocarbon dates IX. Radiocarbon 12(2): 458

Volman TP (1984) Early prehistory of southern Africa. In: Klein RG (ed) Southern African prehistory and paleoenvironments. Rotterdam, A.A. Balkema, pp 169-220

Wadley L (2015) Those marvellous millennia: the Middle Stone Age of Southern Africa. Azania: Archaeol Res Afr 50(2):155-226
Wadley L, Sievers C, Bamford M, Goldberg P, Berna F, Miller CE (2011) Middle Stone Age bedding construction and settlement patterns at Sibudu, South Africa. Science 334:1388-1391

Wadley L, Murungi M, Witelson D, Bohlar R, Bamford M, Sievers C, Val A, de la Peña P (2016) Steenbokfontein 9KR: a Middle Stone Age spring site in Limpopo, South Africa. S Afr Archaeol Bull 71(204):130-145

Watts I (1998) The origins of symbolic culture: the southern African Middle Stone Age and Khoisan ethnography. PhD dissertation. University of London, London

Watts I (2002) Ochre in the Middle Stone Age of southern Africa: ritualized display or hide preservative? S Afr Archaeol Bull 57:64-74

Wilkins J, Chazan M (2012) Blade production $\sim 500$ thousand years ago at Kathu Pan 1, South Africa: support for a multiple origins hypothesis for early Middle Pleistocene blade technologies. J Archaeol Sci 39:1883-1900

Wilkins J, Schoville BJ, Brown KS, Chazan M (2012) Evidence for early hafted hunting technology. Science 338:942-946

Wilkins J, Schoville BJ, Brown KS, Gliganic L, Meyer MC, Loftus E, Pickering R, Collins B, Blackwood AF, Makalima S, Hatton A, Maape S (2020) Fabric analysis and chronology at Ga-Mohana Hill North Rockshelter, Southern Kalahari Basin: evidence for in situ, stratified Middle and Later Stone Age deposits. J Paleol Archaeol 3:336-361. https://doi.org/10.1007/s41982-020-00050-9

Will M, Conard NJ, Tryon CA (2019) Timing and trajectory of cultural evolution on the African continent 200,000-30,000 years ago. In: Sahle Y, Reyes-Centeno H, Bentz C (eds) Modern Human Origins and Dispersal. Words, Bones, Genes, Tools. DFG Centre for Advanced Studies Series. Kerns Verlag, Tübingen, pp 25-72

Wurz S, Bentsen SE, Reynard J, Van Pletzen-Vos L, Brenner M, Mentzer S, Pickering R, Green H (2018) Connections, culture and environments around 100000 years ago at Klasies River main site. Quat Int 495:102-115

Zhao JX, Hu K, Collerson KD, Xu HK (2001) Thermal ionization mass spectrometry U-series dating of a hominid site near Nanjing, China. Geol 29:27-30

Publisher's note Springer Nature remains neutral with regard to jurisdictional claims in published maps and institutional affiliations. 